Acta Protozool. (2019) 58: 93-113

www.ejournals.eu/Acta-Protozoologica

doi:10.4467/16890027AP.19.010.11419

PROTOZOOLOGICA

\title{
Morphology and Ontogenesis of Hemiholosticha pantanalensis nov. spec. (Ciliophora, Hypotrichia, Psilotrichidae)
}

urn:1sid:zoobank.org:pub:CD5225C9-1364-4F39-B37C-D207E268B38D

\author{
Peter V ĎAČNÝ' ${ }^{1}$, Wilhelm FOISSNE R ${ }^{2}$ \\ ${ }^{1}$ Comenius University in Bratislava, Department of Zoology, Bratislava, Slovakia; ${ }^{2}$ Paris Lodron University of Salzburg, FB Ecology \\ and Evolution, Salzburg, Austria
}

\begin{abstract}
The morphology and ontogenesis of a new psilotrichid ciliate, Hemiholosticha pantanalensis, were studied using live observation, protargol impregnation, and scanning electron microscopy. Diagnostic features of the new species include: a medium-sized, almost circular to broadly obovate body with a short anterior projection; two macronuclear nodules with a single micronucleus in between; a total of about 35 cirri arranged in three ventral, one postoral, one right and one left marginal row; three dorsal kineties extending along prominent ribs; an adoral zone occupying about $60 \%$ of body length; and intracellular, eyespot-bearing, green algae almost filling the body. The ontogenesis of $H$. pantanalensis follows the psilotrichid mode, being a mixture of features found not only in various hypotrich taxa but also in other spirotrich groups. Specifically, the oral primordium develops in a deep pouch as in euplotids and oligotrichs, the anlage for the undulating membranes does not produce cirri as in euplotids and some schmidingerothrichids, and the longitudinal ventral cirral row R3 develops from two anlagen as in some amphisiellids and kahliellids. Since psilotrichids are classified in a polytomy of main hypotrich lineages in $18 \mathrm{~S}$ rRNA gene phylogenies, some of their ontogenetic features might be ancient spirotrich plesiomorphies while others might be homoplasies.
\end{abstract}

Keywords: biodiversity, Brazil, intracellular green algae, Pantanal, Psilotrichidae, soil ciliates

\section{INTRODUCTION}

The highly diverse subclass Hypotrichia Stein, 1859a unites small to large ciliates with cirri on the ventral side. These locomotory organelles form rows or distinct groups. Individual cirri may be composed of only

Address for correspondence: Peter Vd'ačný, Department of Zoology, Faculty of Natural Sciences, Comenius University in Bratislava, Ilkovičova 6, 84215 Bratislava, Slovak Republic; E-mail: peter. vdacny@uniba.sk two or three cilia, may be medium-sized and thorn-like or form a large tuft made of many sometimes even more than hundred cilia (Berger 1999, 2006, 2008, 2011; Lynn 2008). Also, the number of cirri on the ventral side spans a wide range from less than twenty in some psilotrichids (Heber et al. 2014, Luo et al. 2019) to several hundred in huge urostylids (Berger 2006). The combination of number and arrangement of cirri creates a tremendous diversity of patterns. This has been used in the classification of hypotrichs since the times of Ehrenberg (1838) and Stein (1859a). However, modern, fine-tuned morphological investigations indicate that just the peak of an iceberg of the hypotrich diversity has been described (Foissner et al. 2002, Hu et al. 
2009, Foissner 2016, Liu et al. 2017). Moreover, many molecular phylogenetic analyses published in the past decades show that the classification of the hypotrich diversity is hopelessly complicated and ontogenetic data are often necessary to understand the morphostatic cirral patterns (for a review, see Berger 2011).

It is well known that morphological diversity results from genetic regulatory programs. The understanding of their evolution (evo-devo) may thus help to reveal the origin and diversification of body plans in a variety of organisms (Carroll et al. 2004, Arthur 2011). The evo-devo approach was introduced into the hypotrich classification by Eigner (1997) and Foissner et al. (2004). Specifically, Foissner et al. (2004) created the CEUU (Convergent Evolution of Urostylids and Uroleptids) hypothesis, i.e., that very similar morphostatic cirral patterns may be produced in distantly related monophyletic groups by comparatively small genetic changes. This has been confirmed by molecular data of, for instance, Foissner and Stoeck (2008), Jung et al. (2014), and Kim et al. (2014). To better understand the evolution and diversity of hypotrichs, we need to know which morphologic and ontogenetic features are plesiomorphies, apomorphies or homoplasies, and which genetic program underpins the development of a particular cirral pattern.

In the present study, we describe the morphology and ontogenesis of a new Hemiholosticha species carrying green algae. According to morphological and molecular data, the peculiar genus Hemiholosticha Gelei, 1954 belongs to the hypotrich family Psilotrichidae Bütschli, 1889 (Heber et al. 2014, Luo et al. 2019). Psilotrichids are classified in a polytomy of the subclass Hypotrichia in 18S rRNA gene phylogenies, which indicates an ancient nature of psilotrichids on one hand and a rapid radiation of main hypotrich lineages on the other one. Psilotrichids are very interesting from the phylogenetic point of view because their somatic ciliature is simple, i.e., frontal, frontoterminal, buccal, pretransverse, transverse and caudal cirri are absent (Heber et al. 2014). In this respect, they resemble euplotids whose somatic ciliature is also weakly differentiated, and which are a sister group to hypotrichs and oligotrichs. Thus, psilotrichids are very interesting also from the ontogenetic point of view, since they display a mixture of ontogenetic features found not only in various groups of hypotrichs (amphisiellids, kahliellids, oxytrichids, and schmidingerothrichids) but also in other spirotrich subclasses (euplotids and oligotrichs). Therefore, we attempt here to put morphology and on- togenesis of psilotrichids into a phylogenetic context of the class Spirotrichea Bütschli, 1889.

\section{MATERIAL AND METHODS}

\section{Sampling and sample processing}

Hemiholosticha pantanalensis nov. spec. was discovered in a soil sample collected by Maria Pichler and Birgit Weissenbacher (University of Salzburg) in the surroundings of kilometre 42 of the Transpantaneira Road between the cities of Poconé and Porto Jofre, near the Pousada Rio Claro, Pantanal wetland, Mato Grosso, Brazil, S16 $39^{\prime}$ 'W56 ${ }^{\circ} 45^{\prime}$. The sample consisted of dusty, light brown soil with some litter and fine roots. It was air-dried for three weeks and sealed in a plastic bag. Ciliates were reactivated from resting cysts, using the non-flooded Petri dish method (Vd'ačný and Foissner 2012). Briefly, the method involves placing 50-500 g air-dried material in a Petri dish (13-18 cm wide, $2-3 \mathrm{~cm}$ high) and saturating, but not flooding it, with distilled water. Such a culture is regularly analysed for ciliates by inspecting about $2 \mathrm{ml}$ of the run-off. To obtain enough dividers, raw cultures were set up in Eau de Volvic (French table water) with a few $\mathrm{ml}$ of the eluate from the non-flooded Petri dish culture and some crashed wheat kernels to stimulate growth of food (bacteria and protists). Unfortunately, no specimens were stored for a molecular analysis because the species was discovered almost $15 \mathrm{yr}$ ago when molecular characterization of ciliates just begun.

\section{Taxonomic methods and terminology}

Morphology and ontogenesis of $H$. pantanalensis nov. spec. were studied using a combination of in vivo observation, protargol impregnation, and scanning electron microscopy (SEM), as described by Foissner $(1991,2014)$. Living cells were examined using a high-power oil immersion objective and differential interference contrast microscopy. Protargol impregnation followed protocol A. Da Fano solution was used for fixation since it generates very good results in Hemiholosticha (Heber et al. 2014). The ontogenetic processes were reconstructed from protargol preparations, which show concomitantly body shape, ciliary pattern, and nuclear apparatus. Scanning electron microscopy supplemented the observations.

In vivo measurements were performed with an ocular micrometer at a magnification of $25-1000 \times$ while counts and measurements on protargol-impregnated specimens were conducted at a magnification of $1250 \times$. Illustrations of live specimens were based on freehand sketches and photographs while those of impregnated cells were made with a drawing device. To illustrate the changes during the morphogenetic processes, parental cirri were depicted by contour whereas new ones were shaded black.

General terminology follows Lynn (2008). Morphostatic terminology is based on Berger (1999, 2006, 2008, 2011) and Heber et al. (2014). Ontogenetic terminology is according to Foissner (1996) and numbering of cirral streaks is according to Heber et al. (2014). Division stages are distinguished as follows: early dividers are characterized by the macronucleus composed of two nodules occupying the central quarters of the cell. In mid-dividers, the macronuclear nodules are fused into a central mass. Late dividers are constricted in the middle and have a dumbbell-shaped macronucleus. 
ZooBank registration number (Recommendation 8A of the International Commission on Zoological Nomenclature 2012) is urn:1sid:zoobank.org:pub:CD5225C9-1364-4F39-B37C-D207E2 $68 \mathrm{~B} 38 \mathrm{D}$. Since this is a taxonomic study, nomenclatural references are also listed in the 'Reference' section.

\section{RESULTS}

\section{Hemiholosticha pantanalensis nov. spec. Foissner and Vd'ačný}

ZooBank registration number: urn:1sid:zoobank. org:act:BE39471F-C249-41E5-97D2-42584EF3FB65.

Diagnosis: Size in vivo about $70 \times 53 \mu \mathrm{m}$; body almost globular to broadly obovate with short anterior projection at distal end of adoral zone; dorsal side with three distinct ribs. Two ellipsoid macronuclear nodules and a single micronucleus in between. On average a total of 35 cirri in three ventral, one postoral, one right and one left marginal row. Two postoral cirri, first localized at level of proximal end of undulating membranes. On average 30 dorsal bristles in three kineties, posterior bristles elongated. Adoral zone extends about $60 \%$ of body length, composed of an average of 21 membranelles. Green intracellular algae with eyespot present.

Type locality: Dusty, light brown soil from the Pantanal wetland, Mato Grosso, Brazil, S16 $39^{\prime}$ W56 $6^{\circ} 45^{\prime}$.

Type material: The holotype slide and two paratype slides with protargol-impregnated specimens have been deposited in the Museum of Natural History (Biologiezentrum) in Linz (LI), Austria. The holotype (Fig. 1B, C) and relevant paratype specimens as well as dividers have been marked by black ink circles on the coverslip.

Etymology: The species-group name pantanalens $\cdot$ is $-i s,-e[\mathrm{~m}, \mathrm{f}, \mathrm{n}]$ is a Latin adjective in nominative singular (Article 11.9.1.1 of the International Commission on Zoological Nomenclature 1999) and refers to the origin of the new species.

Description: Size in vivo $60-76 \times 48-60 \mu \mathrm{m}$, on average $70 \times 53 \mu \mathrm{m}$, i.e., distinctly longer and wider than in protargol and SEM preparations $(50 \times 35 \mu \mathrm{m}$ and $50 \times 33 \mu \mathrm{m})($ Table 1$)$. Body almost globular to broadly obovate with a length:width ratio ranging from 1.1:1 to $1.8: 1$ in protargol preparations; a short anterior projection at distal end of adoral zone; posterior end usually broadly rounded but often narrower than anterior end, rarely acute, especially in ventral view; right cell margin very thin and hence appearing hyaline in vivo (Table 1; Figs $1 \mathrm{~A}-\mathrm{C}, \mathrm{E}-\mathrm{H}, 2 \mathrm{~A}-\mathrm{F}, \mathrm{I}-\mathrm{K}$, $3 \mathrm{~A}-\mathrm{C}, 4 \mathrm{~A})$. Dorsoventrally flattened up to $2: 1$, both sides slightly to moderately convex, dorsal side with three prominent, sharp ribs well recognizable in SEM and in optical cross sections during live observation (Figs 1I, 3B, C, 4A, 5A-D). Nuclear apparatus in central quarters of cell, almost in body midline; invariably composed of two macronuclear nodules and one micronucleus in between. Macronuclear nodules broadly ellipsoid, ellipsoid or ovoid with a length:width ratio of 1.3-2.1:1; size about 9.0-15.0 × 6.0-9.0 $\mu \mathrm{m}$, usually $11.7 \times 7.6 \mu \mathrm{m}$ in protargol preparations; distance between nodules rather variable $(\mathrm{CV}=26.3 \%)$, ranging from $2.0 \mu \mathrm{m}$ to $6.0 \mu \mathrm{m}$; nodules usually connected by a fine strand impregnated with protargol; nucleoli globular and up to $3.0 \mu \mathrm{m}$ across. Micronucleus bright, broadly ellipsoid to ellipsoid, i.e., about $5.0 \times 3.0 \mu \mathrm{m}$ in vivo and 4.0-5.0 $\times 2.0-3.0 \mu \mathrm{m}$, on average $4.5 \times 2.6$ $\mu \mathrm{m}$ in protargol preparations (Table 1; Figs 1A, C, F, 2I-K). Contractile vacuole near body centre; a single excretory pore, about $1.0 \times 0.3 \mu \mathrm{m}$ in SEM, left of middle dorsal rib, not recognizable in protargol preparations (Figs 1A, 2D, F, 5C, D). Cortex inflexible, colourless, lacks specific granules. Cytoplasm colourless but cells appear greenish due to numerous green algae; finely granulated; studded with lipid droplets $0.5-5.0$ $\mu \mathrm{m}$ across and some up to $10 \mu \mathrm{m}$-sized food vacuoles containing Polytoma cysts. Green algae almost fill ciliate's body; $10-13 \times 4-7 \mu \mathrm{m}$ in size in vivo $(n=11)$; ellipsoid to narrowly ellipsoid; with subapical intraplastidial red eyespot (stigma), some starch granules, and comparatively large chloroplast almost completely encircling the cell; division yields four tightly packed daughter cells (Figs 1 J, K, 2G, H, K). Glides and creeps moderately fast on microscope slides, also rests on organic debris.

Cirri firm, thorn-like, $17-20 \mu \mathrm{m}$ long in vivo while only $11-16 \mu \mathrm{m}$ after protargol impregnation and 10-20 $\mu \mathrm{m}$ (on average $13.5 \mu \mathrm{m}$ ) in SEM; total number very stable $(\mathrm{CV}=4.2 \%)$ ranging from 31 to 36 ; arranged in three ventral, one postoral, one right and one left marginal row; frontal, buccal, and transverse cirri not distinguishable (Table 1; Figs 1B, E, 2J). Ventral cirral row R1 invariably composed of two cirri: anterior cirrus near distal end of adoral zone, posterior cirrus slightly anterior to mid-portion of paroral membrane. Ventral cirral row R2 begins $6.0-11.0 \mu \mathrm{m}$ posterior to anterior body end; $5.0 \mu \mathrm{m}$ to $7.0 \mu \mathrm{m}$ long after protargol impregnation; invariably composed of two cirri. 
Table 1. Morphometric data on Hemiholosticha pantanalensis nov. spec.

\begin{tabular}{|c|c|c|c|c|c|c|c|c|}
\hline Characteristics $^{\mathrm{a}}$ & Mean & $\mathrm{M}$ & SD & SE & $\mathrm{CV}$ & Min & $\operatorname{Max}$ & $\mathrm{n}$ \\
\hline Body, length & 49.4 & 50.0 & 4.9 & 1.0 & 10.0 & 40.0 & 57.0 & 23 \\
\hline Body, length in SEM & 49.6 & 49.0 & 6.7 & 1.4 & 13.5 & 40.0 & 73.0 & 23 \\
\hline Body, length in vivo & 69.6 & 70.0 & 4.3 & 1.4 & 6.2 & 60.0 & 76.0 & 10 \\
\hline Body, width & 35.7 & 35.0 & 4.4 & 0.9 & 12.4 & 30.0 & 46.0 & 23 \\
\hline Body, width in SEM & 33.5 & 33.0 & 4.5 & 0.9 & 13.3 & 25.0 & 46.0 & 23 \\
\hline Body, width in vivo & 52.8 & 52.0 & 3.7 & 1.2 & 7.0 & 48.0 & 60.0 & 10 \\
\hline Body length:width, ratio & 1.4 & 1.4 & 0.1 & 0.0 & 10.7 & 1.1 & 1.8 & 23 \\
\hline Anterior projection, height & 2.0 & 2.0 & 0.6 & 0.1 & 28.8 & 1.0 & 3.0 & 21 \\
\hline Macronuclear nodules, number & 2.0 & 2.0 & 0.0 & 0.0 & 0.0 & 2.0 & 2.0 & 23 \\
\hline Micronuclei, number & 1.0 & 1.0 & 0.0 & 0.0 & 0.0 & 1.0 & 1.0 & 21 \\
\hline Anterior body end to anterior macronuclear nodule, distance & 10.5 & 11.0 & 1.1 & 0.2 & 10.2 & 8.0 & 12.0 & 21 \\
\hline Macronuclear nodules, distance in between & 3.7 & 3.0 & 1.0 & 0.2 & 26.3 & 2.0 & 6.0 & 21 \\
\hline Anterior macronuclear nodule, length & 11.7 & 12.0 & 1.7 & 0.4 & 14.9 & 9.0 & 15.0 & 21 \\
\hline Anterior macronuclear nodule, width & 7.6 & 8.0 & 0.7 & 0.2 & 9.9 & 6.0 & 9.0 & 21 \\
\hline Anterior macronuclear nodule length:width, ratio & 1.5 & 1.5 & 0.2 & 0.1 & 14.9 & 1.3 & 2.1 & 21 \\
\hline Nucleoli, maximum diameter & 3.0 & 30.0 & 0.0 & 0.0 & 0.0 & 3.0 & 3.0 & 3 \\
\hline Micronucleus, length & 4.5 & 4.5 & - & - & - & 4.0 & 5.0 & 21 \\
\hline Micronucleus, width & 2.6 & 2.5 & - & - & - & 2.0 & 3.0 & 21 \\
\hline Micronucleus length:width, ratio & 1.4 & 1.3 & 0.2 & 0.0 & 13.7 & 1.2 & 1.8 & 21 \\
\hline Anterior body end to proximal end of AZM, length & 29.4 & 30.0 & 1.8 & 0.4 & 6.1 & 26.0 & 33.0 & 21 \\
\hline Adoral zone of membranelles, percentage of body length & 59.6 & 59.2 & 3.8 & 0.8 & 6.4 & 54.5 & 66.7 & 21 \\
\hline Adoral membranelles, number & 21.2 & 21.0 & 0.8 & 0.2 & 3.8 & 20.0 & 23.0 & 21 \\
\hline Adoral membranelles, length of widest base & 6.5 & 7.0 & - & - & - & 6.0 & 7.0 & 21 \\
\hline Frontal adoral membranelles, length of cilia & 16.4 & 16.0 & 1.5 & 0.4 & 9.2 & 15.0 & 20.0 & 12 \\
\hline Buccal cavity, width & 8.8 & 9.0 & 1.0 & 0.2 & 11.7 & 7.0 & 11.0 & 21 \\
\hline Anterior body end to paroral membrane, distance & 5.9 & 6.0 & 1.4 & 0.3 & 24.3 & 3.0 & 8.0 & 21 \\
\hline Paroral membrane, length & 17.0 & 17.0 & 1.6 & 0.4 & 9.7 & 13.0 & 19.0 & 21 \\
\hline Anterior body end to endoral membrane, distance & 13.7 & 14.0 & 1.7 & 0.4 & 12.4 & 10.0 & 16.0 & 21 \\
\hline Endoral membrane, length & 10.0 & 10.0 & 0.7 & 0.2 & 7.1 & 9.0 & 11.0 & 21 \\
\hline Left marginal cirral row, number of cirri & 5.4 & 5.0 & - & - & - & 5.0 & 6.0 & 21 \\
\hline Postoral cirral row, number of cirri ${ }^{b}$ & 2.0 & 2.0 & 0.0 & 0.0 & 0.0 & 2.0 & 2.0 & 42 \\
\hline Anterior body end to postoral cirral row, distance & 22.3 & 22.0 & 2.2 & 0.5 & 10.0 & 18.0 & 26.0 & 21 \\
\hline Postoral cirral row, length & 10.1 & 10.0 & 1.2 & 0.3 & 12.2 & 8.0 & 13.0 & 21 \\
\hline Ventral cirral row R1, number of cirri & 2.0 & 2.0 & 0.0 & 0.0 & 0.0 & 2.0 & 2.0 & 21 \\
\hline Ventral cirral row R1, length & 4.4 & 4.0 & 0.7 & 0.1 & 15.3 & 3.0 & 6.0 & 21 \\
\hline Ventral cirral row R2, number of cirri & 2.0 & 2.0 & 0.0 & 0.0 & 0.0 & 2.0 & 2.0 & 21 \\
\hline Anterior body end to ventral cirral row R2, distance & 9.0 & 10.0 & 1.7 & 0.4 & 18.9 & 6.0 & 11.0 & 21 \\
\hline Ventral cirral row R2, length & 6.0 & 6.0 & 0.7 & 0.1 & 11.2 & 5.0 & 7.0 & 21 \\
\hline Ventral cirral row R3, number of cirri & 11.5 & 12.0 & 0.6 & 0.1 & 5.2 & 10.0 & 12.0 & 21 \\
\hline Right marginal cirral row, number of cirri & 11.7 & 12.0 & 0.6 & 0.1 & 5.5 & 11.0 & 13.0 & 21 \\
\hline Cirri, total number & 34.5 & 35.0 & 1.4 & 0.3 & 4.2 & 31.0 & 36.0 & 21 \\
\hline Cirri, length & 14.3 & 15.0 & 1.4 & 0.4 & 9.6 & 11.0 & 16.0 & 12 \\
\hline Dorsal kinety 1 , number of bristles & 7.0 & 7.0 & 0.9 & 0.2 & 12.3 & 6.0 & 9.0 & 21 \\
\hline
\end{tabular}




\begin{tabular}{|c|c|c|c|c|c|c|c|c|}
\hline Anterior body end to dorsal kinety 1 , distance & 14.0 & 14.0 & 1.9 & 0.4 & 13.9 & 10.0 & 18.0 & 21 \\
\hline Posterior body end to dorsal kinety 1 , distance & 10.3 & 11.0 & 3.2 & 0.7 & 31.1 & 5.0 & 18.0 & 21 \\
\hline Dorsal kinety 2 , number of bristles & 10.2 & 10.0 & 1.0 & 0.2 & 9.6 & 8.0 & 12.0 & 21 \\
\hline Anterior body end to dorsal kinety 2 , distance & 9.5 & 10.0 & 1.4 & 0.3 & 15.1 & 7.0 & 12.0 & 21 \\
\hline Dorsal kinety 3 , number of bristles & 13.1 & 13.0 & 1.1 & 0.2 & 8.3 & 11.0 & 16.0 & 21 \\
\hline Anterior body end to dorsal kinety 3 , distance & 5.3 & 5.0 & 1.2 & 0.3 & 22.4 & 3.0 & 8.0 & 21 \\
\hline Dorsal bristles, total number & 29.9 & 30.0 & 3.1 & 0.7 & 10.4 & 20.0 & 35.0 & 21 \\
\hline Posterior dorsal bristles, length & 8.4 & 8.0 & 0.7 & 0.2 & 8.1 & 7.0 & 9.0 & 21 \\
\hline Anterior dorsal bristles, length & 3.5 & 3.0 & - & - & - & 3.0 & 4.0 & 21 \\
\hline Intracellular green algae, length in vivo & 10.7 & 11.0 & 1.6 & 0.5 & 15.1 & 7.0 & 13.0 & 11 \\
\hline Intracellular green algae, width in vivo & 5.1 & 4.0 & 1.4 & 0.4 & 27.0 & 4.0 & 7.0 & 11 \\
\hline
\end{tabular}

Ventral cirral row R3 conspicuously longer than R1 and R2; extends from anterior to posterior body end in slightly curved pattern; consists of 10-12 (rarely 13) cirri, anterior cirri more widely spaced than posterior ones. Postoral cirral row typically composed of two cirri; zero, one or three cirri in three out of 45 specimens; anterior cirrus about at level of proximal end of paroral membrane, posterior cirrus near proximal end of adoral zone; distance between postoral cirri ranges from $8.0 \mu \mathrm{m}$ to $13.0 \mu \mathrm{m}$ in protargol preparations, causing problems in discerning the postoral row. Right marginal cirral row begins at anterior body end, extends along body margin following its curvature to terminate near rear body end; consists of 11-13 cirri. Left marginal cirral row commences at level of midportion of adoral zone and terminates at level of right marginal cirral row; composed of five or six cirri (Table 1; Figs 1B, E, 2J, 3A-D, 4A, B).

Dorsal bristles fine, increase in length from 3.0-4.0 $\mu \mathrm{m}$ anteriorly to $7.0-9.0 \mu \mathrm{m}$ posteriorly; total number of bristles moderately variable $(\mathrm{CV}=10.4 \%)$ ranging from 20 to 35; arranged in three meridional rows; posteriormost bristles of second and third row protrude beyond posterior end of cell. Dorsal kinety 1 begins subapically, shortened posteriorly, and composed of 6-9 bristles. Dorsal kineties 2 and 3 also commence subapically but terminate at rear body end, consist of 8-12 and 11-16 bristles, respectively. Caudal cirri absent (Table 1; Figs 1C, D, F, 5A, B).

Adoral zone extends about $60 \%$ of body length on average; commences anteriorly near midline of body and forms a question mark-like pattern in ventral view; composed of an average of 21 membranelles. Individual membranelles composed of four rows of basal bodies: rows 1 and 2 long and ciliated, row 3 slightly shorter and with minute cilia or unciliated according to SEM observations, row 4 minute, very likely unciliated; length of membranellar cilia abruptly increases from $5 \mu \mathrm{m}$ to $20 \mu \mathrm{m}$ in distal half of zone, causing conspicuous frontal membranelles; largest bases of membranelles $10 \mu \mathrm{m}$ wide in vivo while only $6.0-7.0$ $\mu \mathrm{m}$ after protargol impregnation (Table 1; Figs 1A, B, E, 2I-K, 3A-D, 4A-D). Scutum crescentic, emerges slightly anterior to beginning of ventral cirral row R2 and merges into margin of membranellar stripe partially covering frontal membranelles (Figs 3C, D, 4A, B).

Buccal cavity almost as long as ventral portion of adoral zone; about 7.0-11.0 $\mu \mathrm{m}$ wide in protargol preparations; right margin elevates into a conspicuous Cshaped ridge anteriorly merging into scutum and posteriorly into buccal vertex (Table 1; Figs 3A-D, 4A, B). Paroral membrane begins about $6 \mu \mathrm{m}$ posterior to anterior body end; extends crook-like over buccal ridge, resembling the cyrtohymenid pattern; about $17 \mu \mathrm{m}$ long in protargol preparations and shorter than adoral zone proximally and distally; composed of narrowly spaced dikinetids but only one basal body ciliated according to SEM observations; cilia up to $15 \mu \mathrm{m}$ long in vivo, gradually decreasing to $7 \mu \mathrm{m}$ at both ends; posterior portion rarely doubled or triplicated according to SEM observations (Table 1; Figs 1B, E, 2C, E, I, J, 3A-D, $4 \mathrm{~A}-\mathrm{D})$. Endoral membrane begins in mid of buccal cavity, i.e., about $14 \mu \mathrm{m}$ posterior to anterior body end; optically intersects paroral membrane and terminates at 


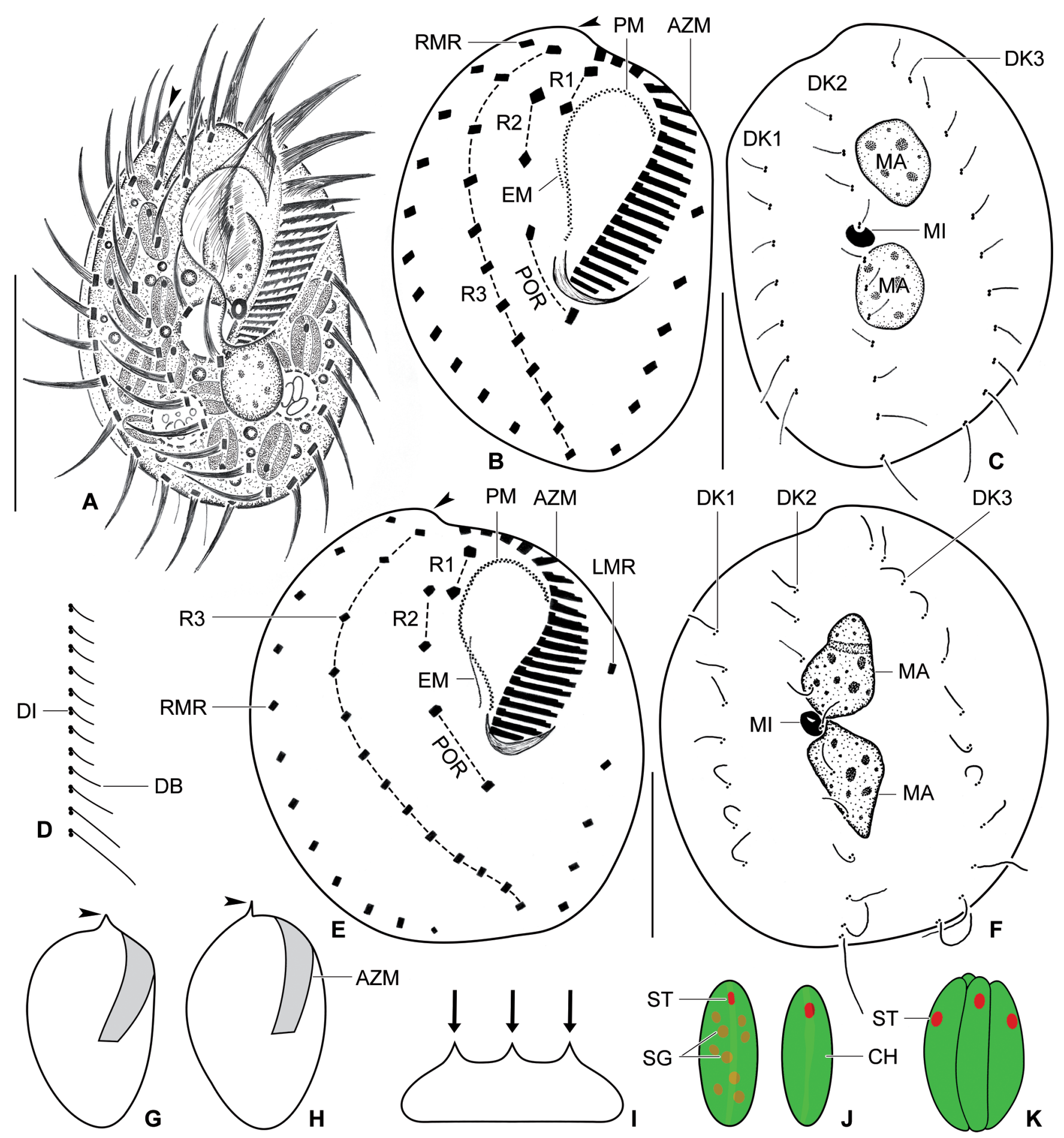

Fig. 1. A-K. Hemiholosticha pantanalensis nov. spec. from life (A, G-K) and after protargol impregnation (B-F). Arrowhead in (A, B, E, $\mathrm{G}, \mathrm{H})$ marks the anterior body projection. A. Ventral view of a representative specimen. B, C, E, F. Ventral and dorsal view of ciliary pattern and nuclear apparatus in holotype (B, C) and in a paratype (E, F) specimen. D. Semi-schematic diagram of a dorsal kinety. G, H. Shape variants. I. Cross section, showing three prominent dorsal ribs (arrows). J. Intracellular green algae contain a subapical red eyespot, starch granules, and a big chloroplast. K. Division of an intracellular green alga yields four tightly packed daughter cells. AZM - adoral zone of membranelles; CH - chloroplast; DB - dorsal bristles; DK1-3 - dorsal kineties; DI - dorsal dikinetids; EM - endoral membrane; LMR - left marginal cirral row; MA - macronuclear nodules; MI - micronucleus; PM - paroral membrane; POR - postoral cirral row; R1-3 - ventral cirral rows; RMR - right marginal cirral row; SG - starch granules; ST - stigma. Scale bars: $20 \mu \mathrm{m}(\mathrm{B}, \mathrm{C}, \mathrm{E}, \mathrm{F})$ and $40 \mu \mathrm{m}$ (A). 

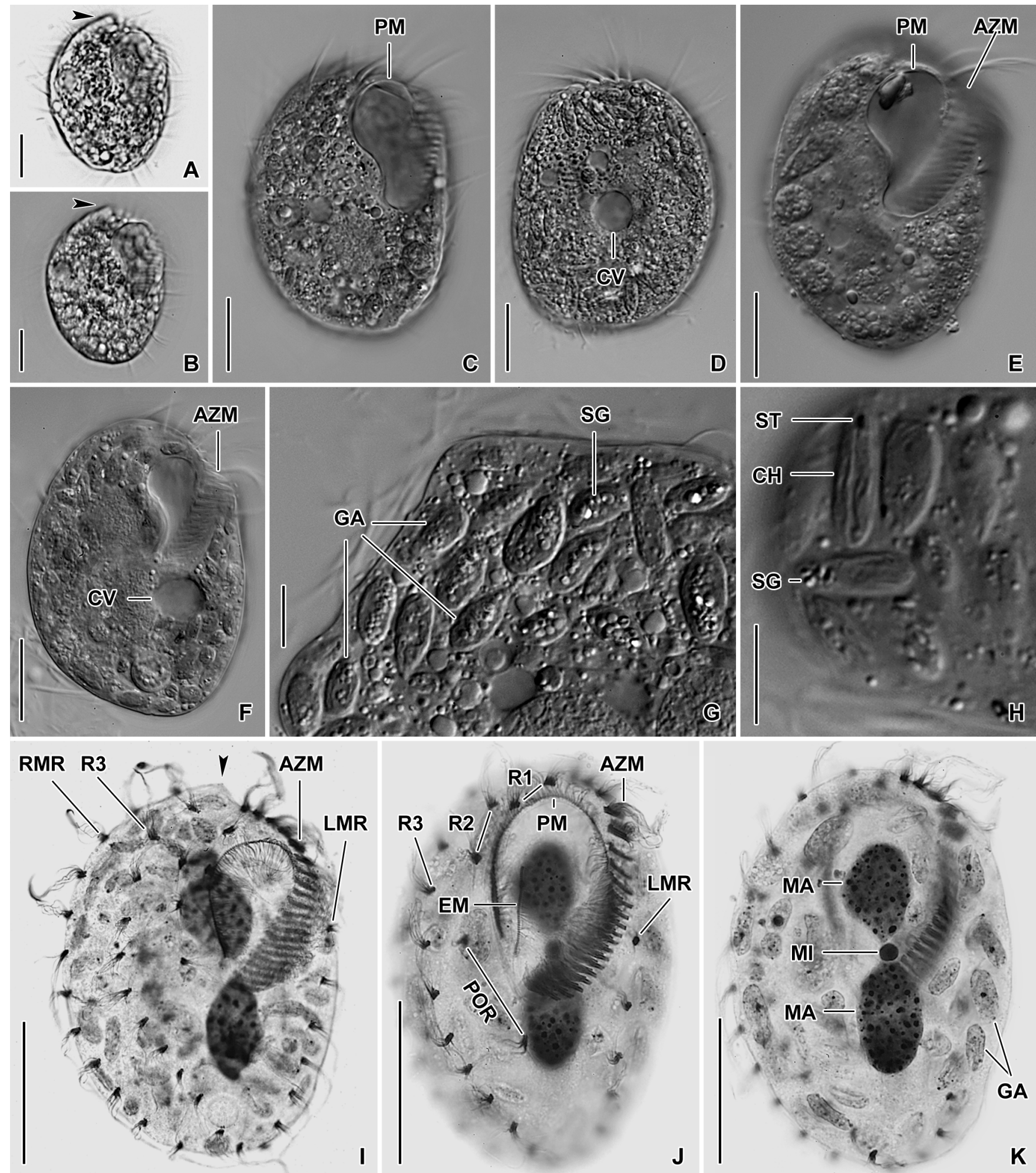

Fig. 2. A-K. Hemiholosticha pantanalensis nov. spec. from life (A-H) and after protargol impregnation (I-K). Arrowhead in (A, B, I) marks the anterior body projection. A-F. Ventral and dorsal (D) overviews, showing general body organization. G, H. Intracelullar green algae contain a subapical red eyespot, starch granules, and a big chloroplast. I-K. Ventral views, showing the ciliary pattern and nuclear apparatus. AZM - adoral zone of membranelles; CH - chloroplast; CV - contractile vacuole; EM - endoral membrane; GA - intracelullar green algae; LMR - left marginal cirral row; MA - macronuclear nodules; MI - micronucleus; PM - paroral membrane; POR - postoral cirral row; R1-3 - ventral cirral rows; RMR - right marginal cirral row; SG - starch granules; ST - stigma. Scale bars: $10 \mu \mathrm{m}(\mathrm{G}, \mathrm{H})$ and $20 \mu \mathrm{m}(\mathrm{A}-\mathrm{F}, \mathrm{I}-\mathrm{K})$. 

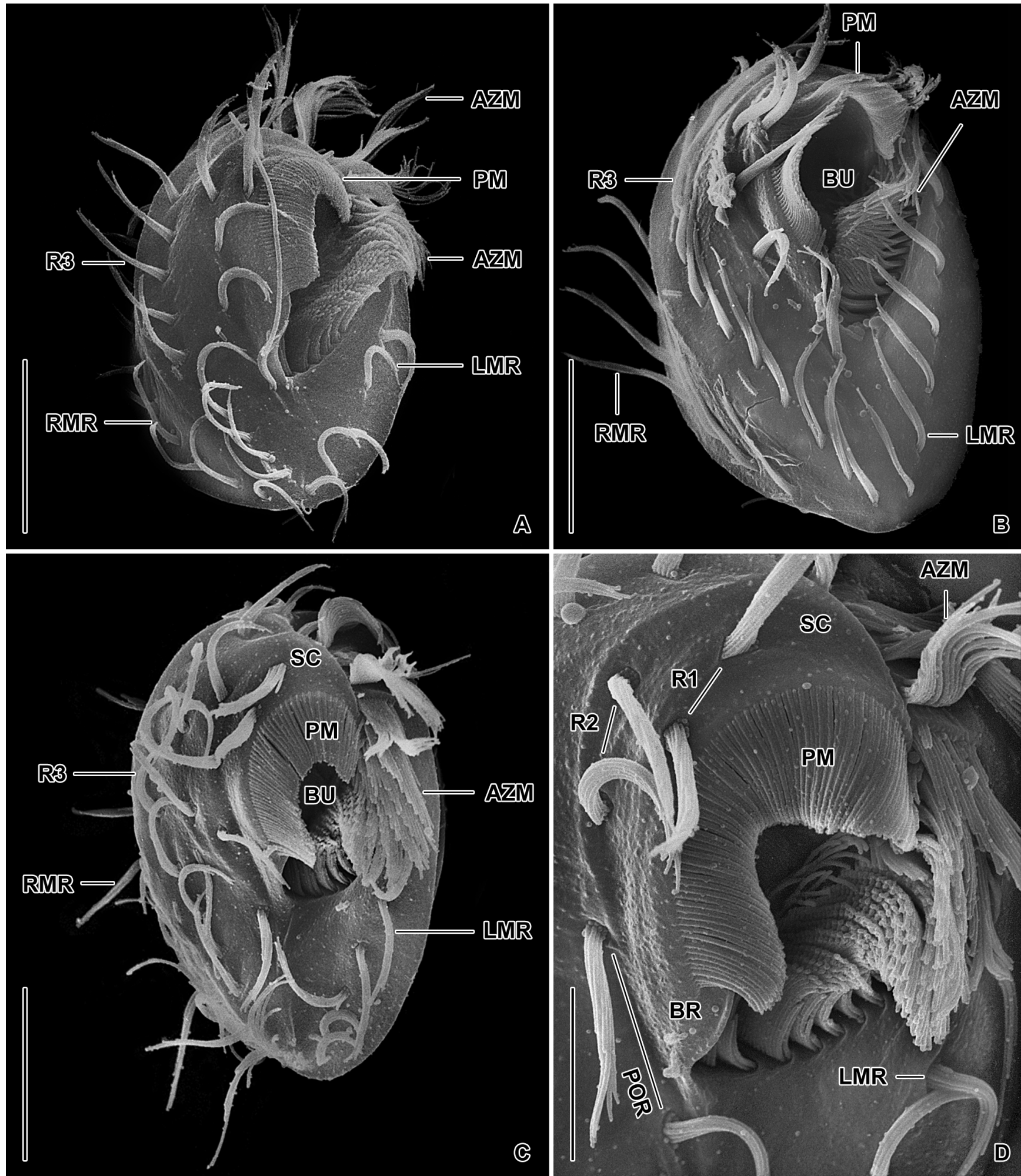

Fig. 3. A-D. Hemiholosticha pantanalensis nov. spec. in the SEM. A-C. Overviews, showing general body organization. D. Detail of oral apparatus of the specimen shown in (C). The paroral membrane is C-shaped and extends on the buccal ridge. The length of the adoral cilia abruptly decreases in the proximal half of the adoral zone. AZM - adoral zone of membranelles; BR - buccal ridge; BU - buccal cavity; LMR - left marginal cirral row; PM - paroral membrane; POR - postoral cirral row; R1-3 - ventral cirral rows; RMR - right marginal cirral row; $\mathrm{SC}$ - scutum. Scale bars: $10 \mu \mathrm{m}$ (D) and $20 \mu \mathrm{m}(\mathrm{A}-\mathrm{C})$. 

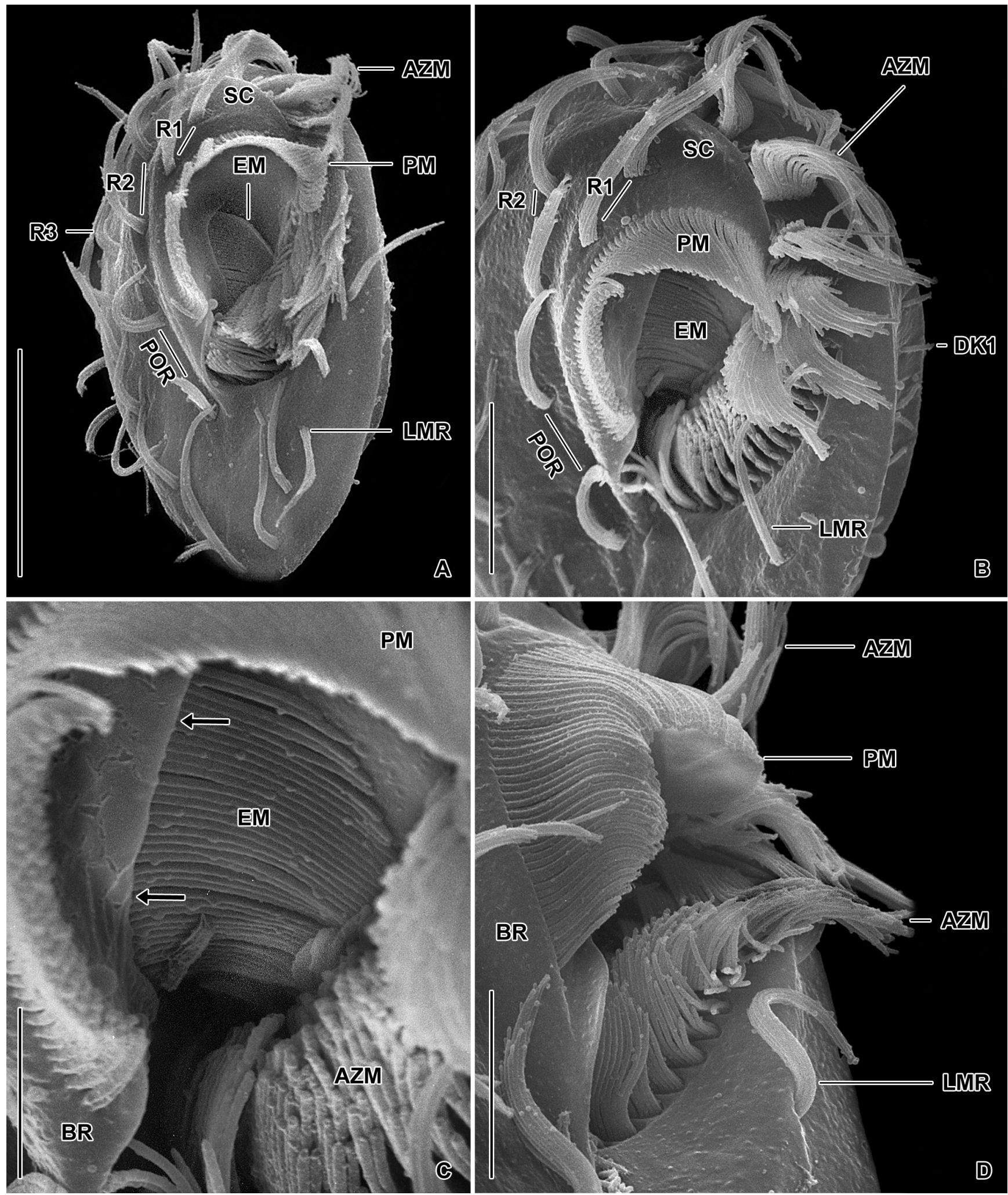

Fig. 4. A-D. Hemiholosticha pantanalensis nov. spec. in the SEM. A. Ventral overview. B-D. Details of oral apparatus; arrows in (C) mark the buccal seal. AZM - adoral zone of membranelles; BR - buccal ridge; DK1 - dorsal kinety; EM - endoral membrane; LMR - left marginal cirral row; PM - paroral membrane; POR - postoral cirral row; R1-3 - ventral cirral rows; SC - scutum. Scale bars: $5 \mu \mathrm{m}(\mathrm{C}), 10 \mu \mathrm{m}$ $(\mathrm{B}, \mathrm{D})$, and $20 \mu \mathrm{m}(\mathrm{A})$. 

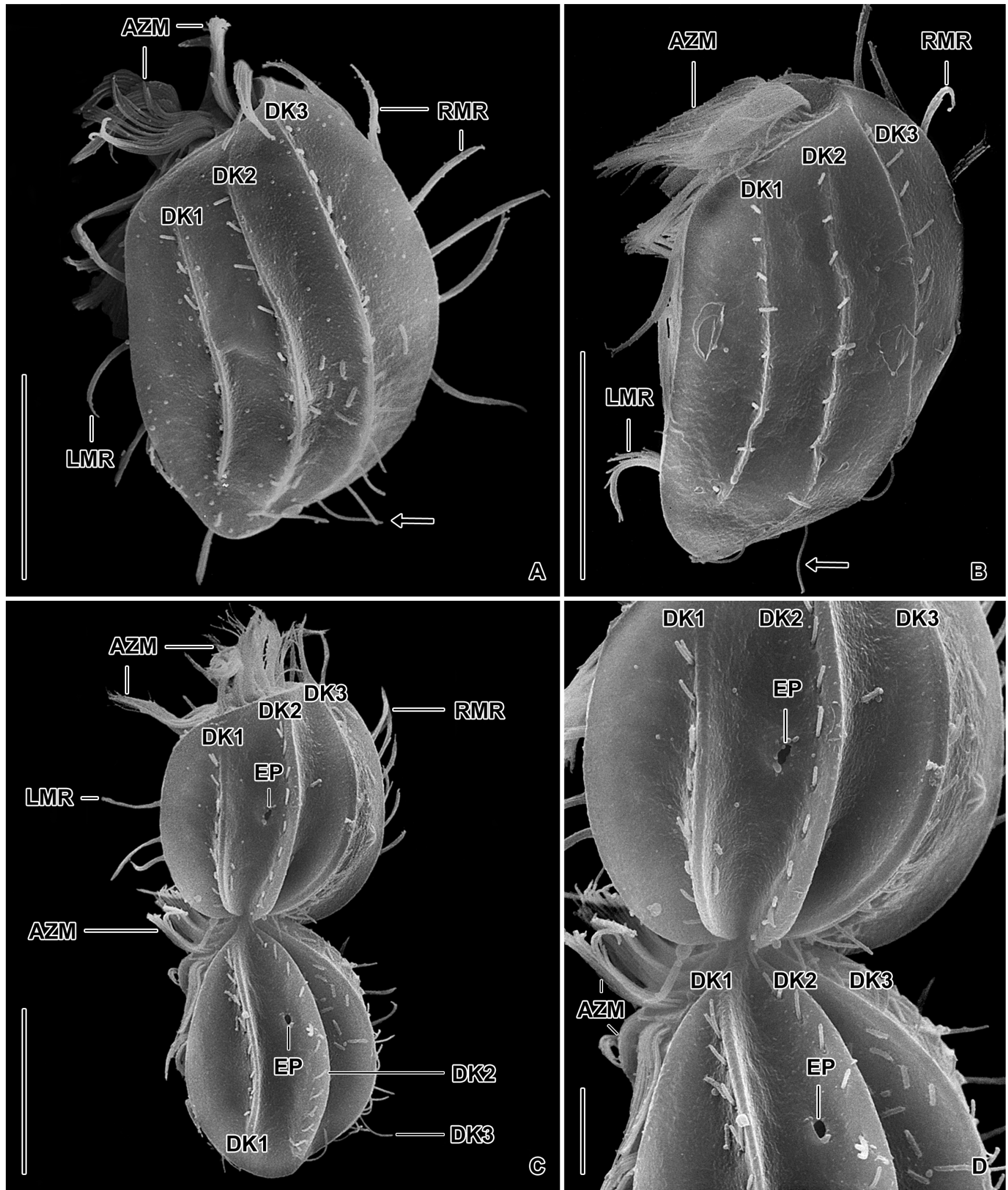

Fig. 5. A-D. Hemiholosticha pantanalensis nov. spec. in the SEM. A, B. Dorsal overviews, showing the three ribs. Arrows mark long posterior bristles. C. Dorsal view of a late divider. D. Detail of fission area of the divider shown in (C). AZM - adoral zone of membranelles; DK1-3 - dorsal kineties; EP - excretory pores; LMR - left marginal cirral row; RMR - right marginal cirral row. Scale bars: $5 \mu \mathrm{m}$ (D) and $20 \mu \mathrm{m}(\mathrm{A}-\mathrm{C})$. 
level of or slightly posterior to its proximal end; about $10 \mu \mathrm{m}$ long in protargol preparations and hence distinctly shorter than paroral membrane; composed of densely spaced basal bodies; cilia $7 \mu \mathrm{m}$ long in vivo, form a plate-like structure at bottom of buccal cavity indicating that they might be motionless (Table 1; Figs 1B, E, 2J, 4A-C). Buccal seal present in some specimens (Fig. 4A-C).

\section{Ontogenesis of Hemiholosticha pantanalensis}

Division mode: Binary fission is homothetogenic and occurs in freely motile condition. Stomatogenesis is apokinetal and the parental oral structures are not involved in the formation of the daughter oral ciliature, although the parental undulating membranes are reorganised.

Adoral zone of membranelles and undulating membranes: Stomatogenesis commences with de novo (apokinetal) proliferation of basal bodies close to the posterior postoral cirrus, i.e., very near to the buccal vertex (Figs 6A, B, 8A, B). The growing anarchic field soon invaginates into a deep pouch which contains densely and irregularly arranged protomembranellar basal bodies. The growing cilia of the protomembranelles are thus covered by the cortex and only some are visible through the ovate opening of the pouch in the SEM micrographs (Fig. 8C, D). However, the parental postoral cirrus and some densely arranged basal bodies bearing short cilia do not sink into the pouch but remain on its right margin (Fig. 8D, arrow). According to protargol preparations, these narrowly spaced basal bodies are very likely derived from the right anterior portion of the oral primordium and will form a long dikinetal streak, i.e., the anlage for the undulating membranes of the opisthe (Fig. 6C, D, F, arrows). In the meantime, the protomembranelles start to differentiate from right to left in a posteriad direction. The new adoral zone extends anteriorly between the parental adoral zone and the left marginal cirral row (Fig. 6C, D, F). The distal adoral membranelles evaginate on the cell surface while the proximal membranelles are still forming inside the pouch (Fig. 9A-D). The opisthe's adoral zone is fully developed before macronuclear fusion in middividers (Fig. 6F). Formation of the new paroral and the new endoral membrane is, however, accomplished in mid-dividers by splitting the opisthe's undulating membrane anlage (Fig. 7A, C). Both membranes attain their specific morphology and position in late dividers and/or post-dividers (Figs 7E, G, 9C, D, 10A, B).
The parental adoral zone does not show any sign of reorganization. On the other hand, reorganization of the parental undulating membranes commences already in early dividers, i.e., after evagination of opisthe's anteriormost adoral membranelles (Figs 6F, asterisk, 9A, B, arrows). In mid-dividers, the new proter's undulating membranes are arranged in parallel whereby the endoral membrane begins in mid of buccal cavity resembling the Stylonychia pattern (Fig. 7A, C). The species specific Cyrtohymena-like pattern is obtained in late dividers (Fig. 7G).

Cirral streaks: Five streaks of basal bodies develop both in proter and opisthe. In the proter, streak I forms near the posterior cirrus of parental ventral row R1; streak II appears near the posterior cirrus of parental ventral row R2; and streaks III-V develop within parental ventral row R3. In the opisthe, streaks I and II appear anterior to the opisthe's undulating membrane anlage and are possibly derived from the oral primordium (Figs 6C, D, 8D); streak III forms very likely by the dedifferentiated parental anterior postoral cirrus; and streaks IV and V develop within parental ventral row R3 slightly posterior to proter's streaks III-V. All streaks elongate posteriorly and start to produce cirri already in early dividers (Fig. 6C, D, F). Streak I generates two cirri of ventral row R1; streak II forms two cirri of ventral row R2; streak III produces two cirri migrating leftwards and posteriorly to form the postoral row; streak IV forms three cirri of the anterior portion of ventral row R3; and streak $\mathrm{V}$ forms the remainder cirri of the posterior portion of row R3, as indicated by a break in this row in some mid-dividers (Fig. 7A, arrows) as well as by the different spacing of the three or four anteriormost cirri in vegetative cells (Fig. 1B, E). The new cirral rows migrate to their species-specific positions in late mid-dividers and late dividers. The majority of parental cirri becomes resorbed in late dividers and early post-dividers (Fig. 7A, C, E, G).

Marginal and dorsal anlagen: Formation of new marginal cirral rows and dorsal kineties proceeds as usual for psilotrichids. The proter's left and right marginal row anlagen develop at the anterior end of the parental marginal cirral rows, very likely by dissociation of their anteriormost cirri. The opisthe's left and right marginal row anlagen are formed within the parental marginal cirral rows at about level of the oral primordium (Fig. 6C, D). The marginal row anlagen extend posteriorly, gradually producing new cirri already in early dividers (Fig. 6F). The parental marginal cirri are almost completely re- 

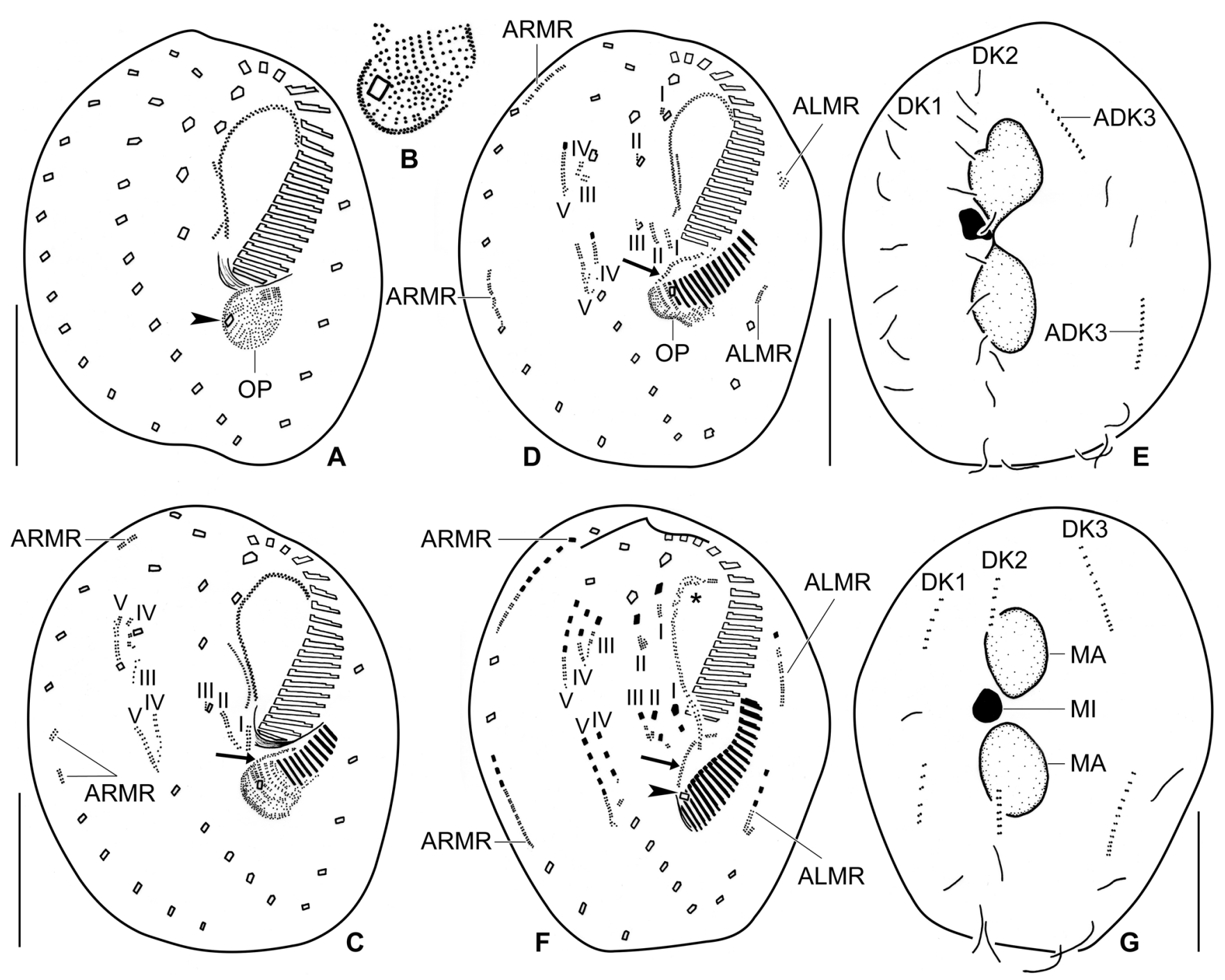

Fig. 6. A-G. Hemiholosticha pantanalensis nov. spec., ciliary pattern and nuclear apparatus of early dividers after protargol impregnation. Parental cirri depicted by contour, new ones shaded black. Arrow in (C, D, F) marks the undulating membrane anlage; arrowhead in $(\mathrm{A}, \mathrm{F})$ denotes the posterior postoral cirrus, and asterisk in (F) marks the reorganizing parental undulating membranes. A. Ventral view of a very early divider, showing the oral primordium close to the posterior postoral cirrus (arrowhead), i.e., just posterior of the buccal vertex. B. Detail of the oral primordium growing around the posterior postoral cirrus. The oral primordium develops in a deep pouch, as typical of psilotrichids, and consists of densely and irregularly arranged basal bodies that will produce the opisthe's adoral zone of membranelles. C. Ventral view, showing that the opisthe's undulating membrane anlage (arrow) develops from the oral primordium. Five cirral streaks appear in the opisthe: the first two are possibly derived from the oral primordium, the third streak forms near the anterior cirrus of the postoral row, and streaks IV and V develop within ventral cirral row R3. At this stage, the proter's right marginal cirral row anlage appears at the anterior end of the parental row, very likely by dissociation of its anteriormost cirri. The opisthe's right marginal cirral row anlage is formed within the parental row at the level of the oral primordium. D-G. Ventral and dorsal views, showing five cirral streaks developing both in proter and opisthe. Formation of new marginal cirral rows and of dorsal kineties proceeds as usual for psilotrichids. Specifically, the proter's left and right marginal cirral row anlagen develop at the anterior end of the parental marginal cirral rows. The opisthe's left and right marginal cirral row anlagen are formed within the parental marginal cirral rows at the level of the oral primordium. The marginal cirral row anlagen gradually produce new cirri posteriorly. Morphogenesis of the dorsal ciliature begins by formation of within-row primordia in the third dorsal kinety at two sites, anterior and posterior to the fission area, separated by two parental bristles (E). The primordia of the first and second dorsal kinety develop later on and are produced in a similar way, that is, by proliferation of basal bodies at two sites which are separated by some parental bristles. The new dorsal kineties reach their final length and structure in mid-dividers (cp. Fig. 6G with Fig. 7B, D). I-V - cirral streaks; ADK3 - anlagen of dorsal kinety 3; ALMR - anlagen of left marginal cirral row; ARMR - anlagen of right marginal cirral row; DK1-3 - dorsal kineties; MA - macronuclear nodules; MI - micronucleus; OP - oral primordium. Scale bars: $20 \mu \mathrm{m}$. 

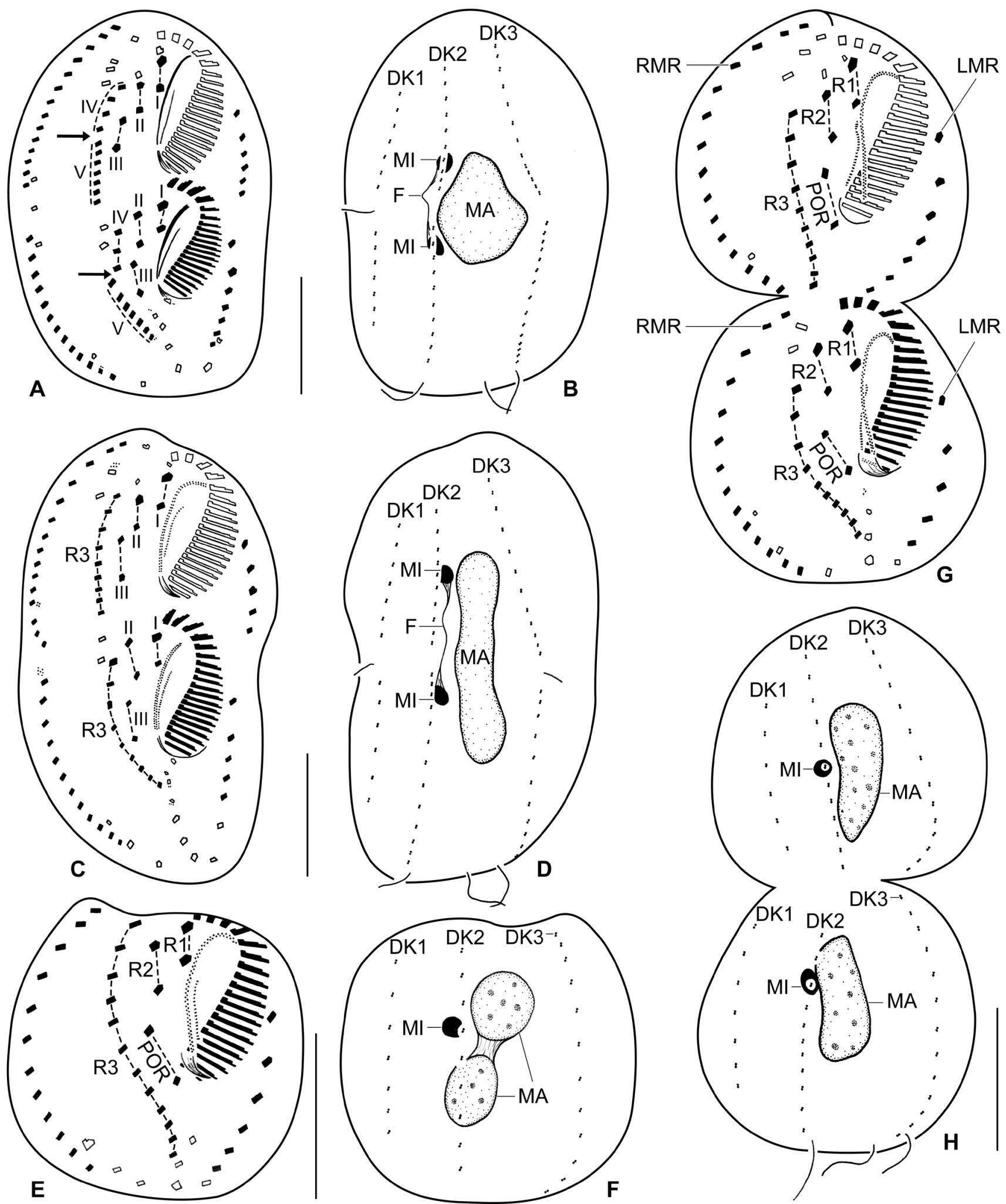

Fig. 7. A-H. Hemiholosticha pantanalensis nov. spec., ciliary pattern and nuclear apparatus of mid-dividers (A-D), of a late divider $(\mathrm{G}, \mathrm{H})$, and of a post-divider (E, F) after protargol impregnation. Arrow in (A) indicates that ventral cirral row R3 forms from anlagen IV and V. I-V - cirral streaks; DK1-3 - dorsal kineties; F - fibres; LMR - left marginal cirral row; MA - macronucleus; MI - micronucleus; POR - postoral cirral row; R1-3 - ventral cirral rows; RMR - right marginal cirral row. Scale bars: $20 \mu \mathrm{m}$. 
sorbed and replaced by new cirri during the mid- and late division stages (Fig. 7A, C, G).

Morphogenesis of the dorsal side ciliature begins already in early dividers. Within-row primordia first appear in the third dorsal kinety at two sites, viz., anterior and posterior to the prospective fission area, separated by two parental bristles that are resorbed later (Fig. 6E). The primordia of the first and second dorsal kineties develop later on and are produced in a similar way, i.e., by proliferation of basal bodies at two sites (Fig. 6G). The new dorsal kineties get their final length in middividers when most parental dorsal bristles are already resorbed (Fig. 7B, D).

Nuclear division: The nuclear apparatus divides as typical for bimacronucleate hypotrichs. Specifically, each macronuclear nodule shows a replication band during the early stages of ontogenesis. In mid-dividers, both nodules fuse into a centrally located mass (Fig. 7B) which elongates (Fig. 7D) and divides into two oblong and pointed pieces (Fig. 7H). Each piece divides once in post-dividers, producing two macronuclear nodules (Fig. 7F).

The micronucleus divides only once after fusion of the macronuclear nodules during the middle divisional stages. The daughter micronuclei are connected by a fibre bundle that elongates in late mid-dividers (Fig. 7B, D) and disappears in late dividers (Fig. 7H). The micronucleus moves to the species-specific position in post-dividers when the two macronuclear nodules have settled (Fig. 7F).

\section{DISCUSSION}

\section{The new species Hemiholosticha pantanalensis}

The comparison of $H$. pantanalensis with congeners is a complex matter because of the confused nomenclatural and taxonomic history of Hemiholosticha. Heber et al. (2014) recognized two Hemiholosticha species in their revision of psilotrichids: $H$. viridis Gelei, 1954 (type species) and Psilotricha viridis (Penard, 1922) sensu Kahl (1932). Kahl (1932) obviously misidentified his population as $P$. viridis Penard, 1922 (basionym: Balladyna viridis Penard, 1922). Balladyna viridis Penard, 1922 is now classified as incertae sedis because it displays transverse cirri which are not present in psilotrichids (Heber et al. 2014). Luo et al. (2019) re-described P. viridis sensu Kahl (1932), provided an accurate map of its cirral pattern, and endowed it with a new name, Hemiholosticha kahli Luo et al., 2019. Hemiholosticha viridis Gelei, 1954 was involved in secondary homonymy when combined with the genus Psilotricha Stein, 1859b by Stiller (1974). She proposed a nomen novum, Psilotricha geleii Stiller, 1974. Since this species is presently not classified in Psilotricha (Heber et al. 2014), its valid name is $H$. viridis Gelei, 1954 according to Article 59.4 of the International Commission on Zoological Nomenclature (1999). Psilotricha viridis sensu Dingfelder (1962) is very likely conspecific with $H$. viridis.

All Hemiholosticha species are highly similar in body shape, the nuclear apparatus, the localization of the contractile vacuole, and in the presence of intracellular green algae. However, $H$. pantanalensis differs from $H$. kahli by the relatively longer adoral zone of membranelles ( $\sim 55-67 \%$ vs. $45-53 \%$ of body length) and by the slightly higher total number of cirri (31-36, on average 35 vs. $29-33$, on average 31). Further, H. kahli usually displays three postoral cirri and the first postoral cirrus is situated almost at the level of the proximal end of the adoral zone while $H$. pantanalensis typically possesses two postoral cirri, the first situated at level of proximal end of the undulating membranes. Due to the lack of ontogenetic data, Luo et al. (2019) very likely incorrectly classified the first postoral cirrus as the last third cirrus of ventral row R2. Further, they stated that there are one or two postoral cirri. If our assumption is correct, then $H$. kahli has invariably two cirri in ventral row R2 as does $H$. pantanalensis but both differ in the number and location of the postoral cirri.

Hemiholosticha pantanalensis is distinguished from $H$. viridis by having a higher number of adoral membranelles (20-23 vs. 13-14) and cirri (31-36 vs. 19-24) as well as by the length of the posterior dorsal bristles (elongated vs. short). Both species further differ by the morphology of the dorsal side (inconspicuous vs. sharp and prominent ribs).

\section{Intracellular eyespot-bearing algae of psilotrichids}

The nature of relationship between ciliates and intracellular algae ranges from a merely intermittent association through kleptoplastidy to a fully established endosymbiosis (Esteban et al. 2010). Although algal symbionts of ciliates are overwhelmingly Chlorella-like members of the class Trebouxiophyceae, psilotrichids contain members of the order Chlamydomonadales from the class Chlorophyceae (Esteban et al. 2010, Heber et al. 2014, Luo et al. 2019). Green or colorless chlamydomonads reported from psilotrichids consistently 

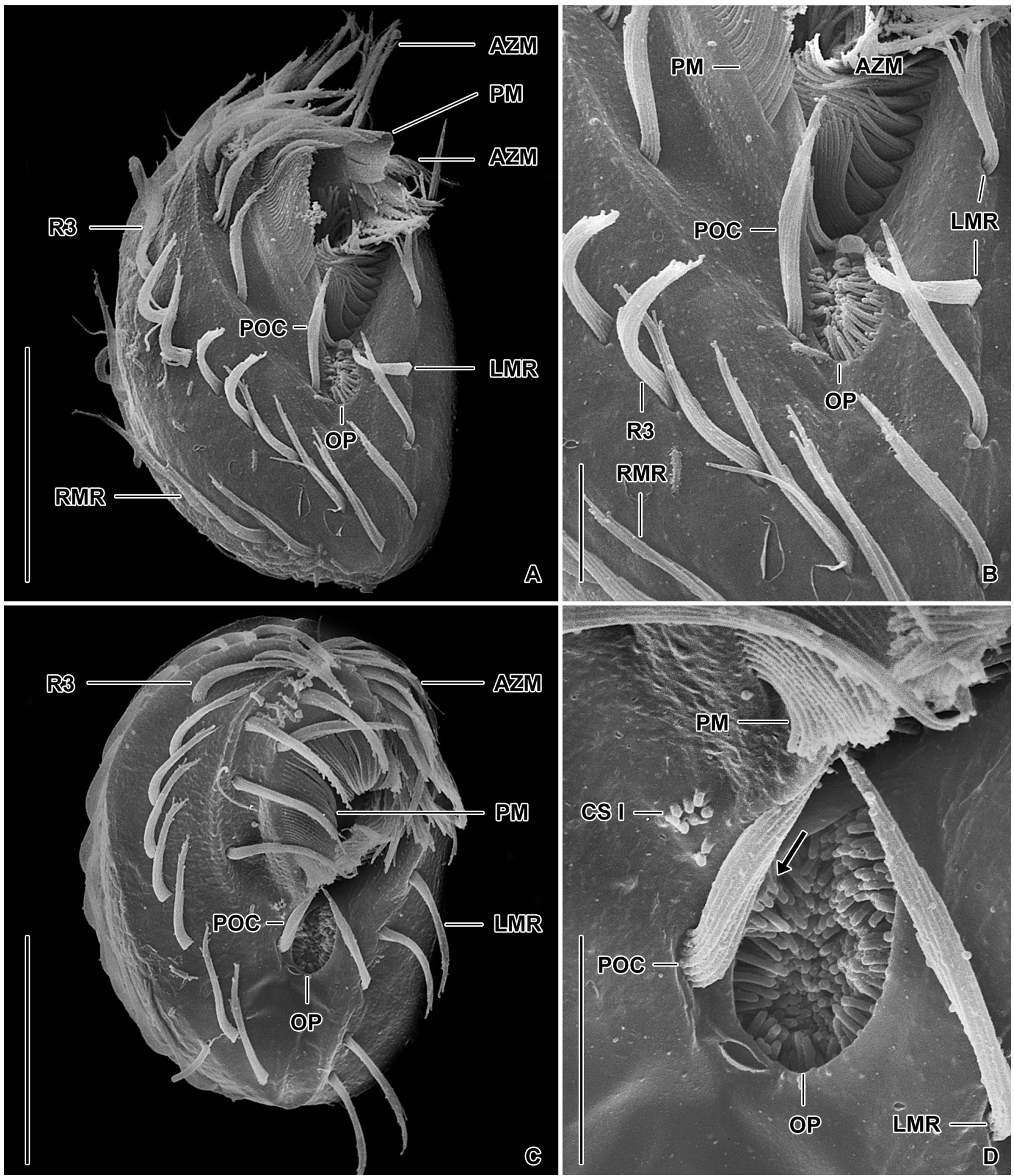

Fig. 8. A-D. Hemiholosticha pantanalensis nov. spec., early dividers in the SEM. A, C. Ventral overviews. B, D. Details of specimens shown in (A, C). The oral primordium develops near the posterior postoral cirrus and soon invaginates into a pouch. Arrow in (D) marks some short cilia that do not sink into the pouch but remain on its right margin very likely forming the opisthe's undulating membranes. AZM - adoral zone of membranelles; CS I - cirral streak I; LMR - left marginal cirral row; OP - oral primordium; PM - paroral membrane; POC - posterior postoral cirrus; R3 - ventral cirral row 3; RMR - right marginal cirral row. Scale bars: $5 \mu \mathrm{m}(\mathrm{B}, \mathrm{D})$ and $20 \mu \mathrm{m}(\mathrm{A}, \mathrm{C})$. 


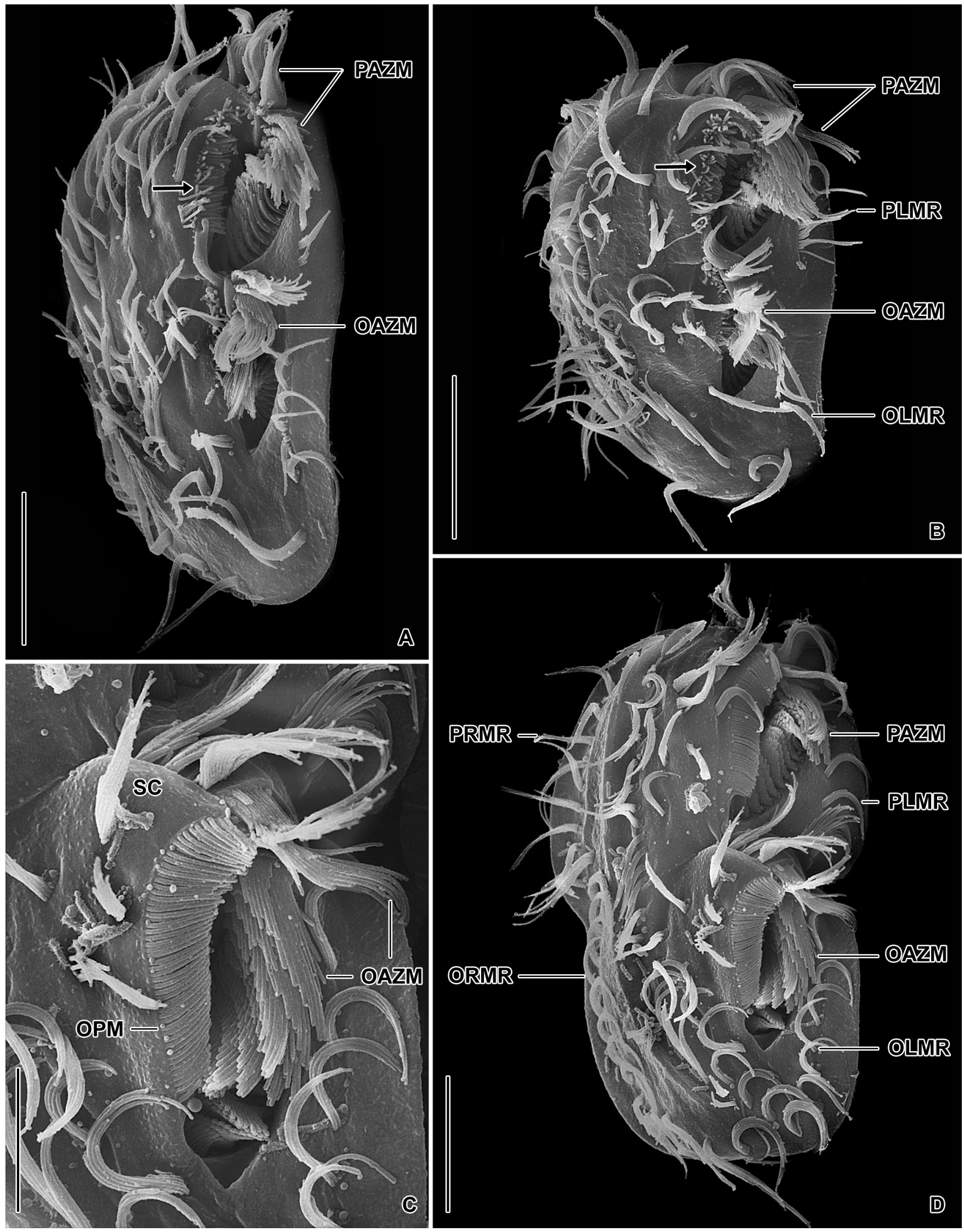



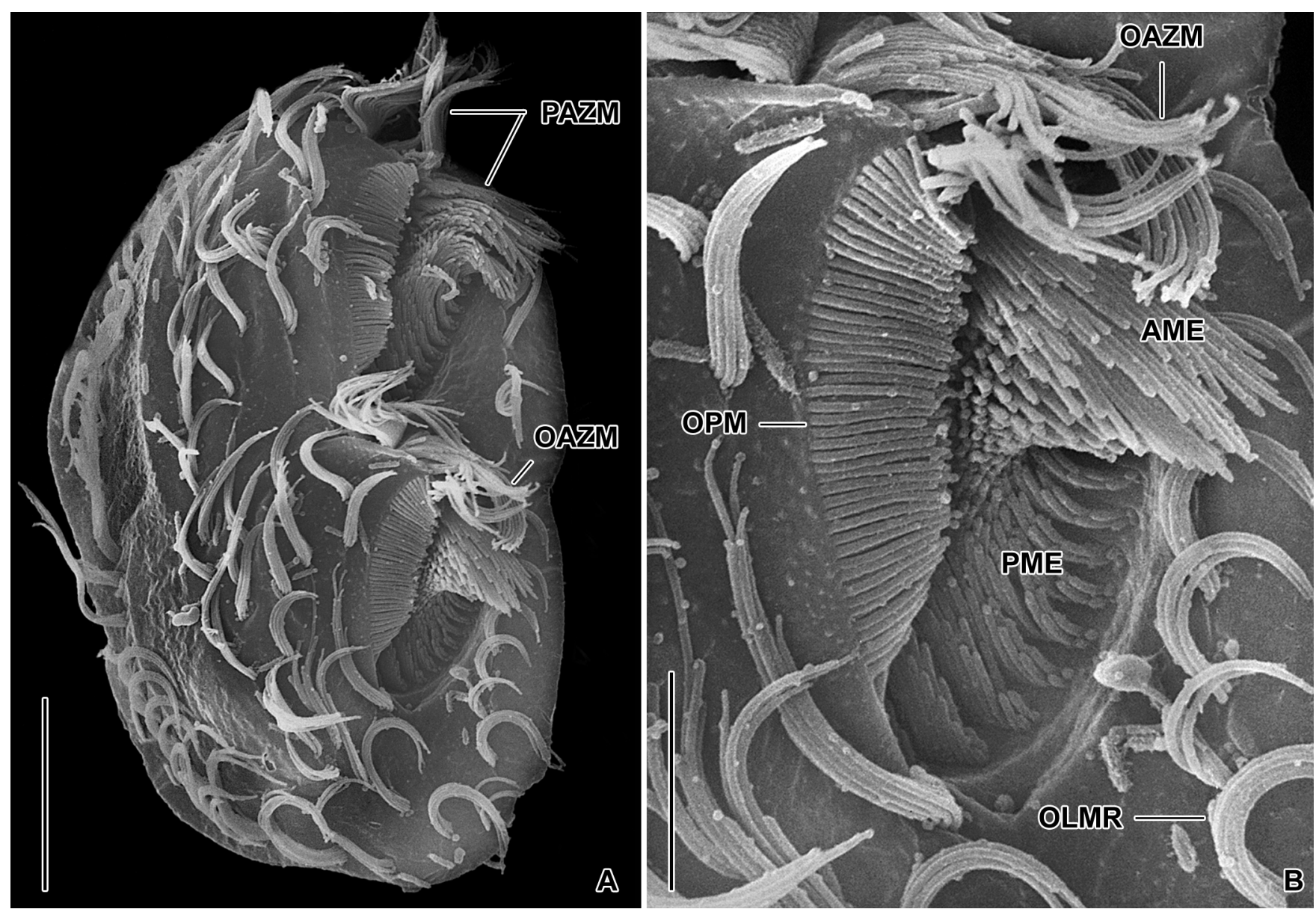

Fig. 10. A, B. Hemiholosticha pantanalensis nov. spec., a late divider in the SEM. A. Ventral overview. B. Detail of opisthe's oral apparatus. The adoral zone is already evaginated and almost fully developed, i.e., consists of long new anterior membranelles and of short posterior membranelles. The paroral membrane has, however, not got the cyrtohymenid C-shape. AME - anterior membranelles; OAZM - opisthe's adoral zone of membranelles; OLMR - opisthe's left marginal row; OPM - opisthe's paroral membrane; PAZM - proter's adoral zone of membranelles; PME - posterior membranelles. Scale bars: $10 \mu \mathrm{m}$ (B) and $20 \mu \mathrm{m}(\mathrm{A})$.

\section{4}

Fig. 9. A-D. Hemiholosticha pantanalensis nov. spec., mid-dividers (A, B) and a late divider (C, D) in the SEM. A, B, D. Ventral overviews. Arrows in (A, B) mark the reorganizing parental undulating membranes. C. Detail of opisthe's oral apparatus of the specimen shown in (D). OAZM - opisthe's adoral zone of membranelles; OLMR - opisthe's left marginal cirral row; OPM - opisthe's paroral membrane; ORMR - opisthe's right marginal cirral row; PAZM - proter's adoral zone of membranelles; PLMR - proter's left marginal cirral row; PRMR - proter's right marginal cirral row; SC - scutum. Scale bars: $10 \mu \mathrm{m}(\mathrm{C})$ and $20 \mu \mathrm{m}(\mathrm{A}, \mathrm{B}, \mathrm{D})$.

display red or orange eyespots (Kahl 1932, Kreutz 2008, Esteban et al. 2010, Heber et al. 2014, Luo et al. 2019, present study). However, eyespots are typically associated with flagellar movement and hence would be useless in endosymbionts. Luo et al. (2019) speculated that the vacuoles surrounding algae in the German population of H. kahli, reported by Kreutz (2008), resemble food vacuoles rather than perialgal vacuoles which are typically almost indiscernible from the algal cell wall. Moreover, they noted that some "colorless" flagellates might be green forms in various stages of digestion. The Guam population of $H$. kahli, studied by Luo et al. (2019), also provides an indication of digestion of intracellular algae in that their size decreases from the anterior to the posterior end of the ciliates, possibly reflecting cyclosis. The type population of Psilotrichides 
hawaiiensis contained two colorless, eyespot-bearing, chlamydonomad flagellates (Hyalogonium and Polytoma), which very likely also represent prey organisms (Heber et al. 2014). However, the Guam population of $P$. hawaiiensis exhibited green, eyespot-bearing algae indistinguishable from those of $\mathrm{H}$. kahli from the same site (Luo et al. 2019). The presence of eyespots and possible cyclosis indicates that these intracellular algae may be food organisms which are slowly digested due to the thick-walled algal cells. Therefore, Luo et $a l$. (2019) suggested that $H$. kahli may represent a species with high prey selectivity to flagellates of the order Chlamydomonadales. Since the fate of algae ingested by heterotrophic ciliates is not a simple food/symbiont dichotomy, it is difficult to state whether the intracellular, eyespot-bearing algae represent a selective prey that is only slowly digested or an early stage of endosymbiosis. Eco-physiological experiments are needed to more adequately address the nature of relationship between intracellular algae and various psilotrichids including $H$. pantanalensis.

\section{Comparative ontogenesis}

Ontogenesis has been so far investigated in three psilotrichid species, viz., in Urospinula succisa (Müller, 1786) Esteban et al., 2001 by Foissner (1983), in Psilotrichides hawaiiensis Heber et al., 2018 by Heber et al. (2014), and in Hemiholosticha pantanalensis nov. spec. (present study). With respect to most other hypotrichs, psilotrichids exhibit a combination of three outstanding features: (1) the oral primordium develops in a deep pouch, (2) the undulating membranes anlage does not produce cirri, and (3) the postoral cirral row originates as a migrating kinetofragment. The first feature occurs also in other groups of spirotrichs but not in other hypotrichs, the second feature has been so far detected only in euplotids and in one other group of hypotrichs, and the last feature is unique to psilotrichids. These three features are discussed below in a phylogenetic viewpoint.

The oral primordium develops in a deep pouch also in two other spirotrich groups, the euplotids and oligotrichs, while it typically forms on the surface or in a shallow concavity in hypotrichs (Foissner 1996, Lynn 2008). This indicates that the deep pouch might be an ancient plesiomorphy of spirotrichs, as already speculated by Heber et al. (2014). However, development of the oral primordium within a pouch might have also evolved independently in psilotrichids, as a consequence of the reduced size of the posterior body region.
In addition to psilotrichids, the undulating membrane anlage does not produce cirri in euplotids (e.g., Jiang et al. 2010 and references therein) and in two peculiar hypotrich species, i.e., in Schmidingerothrix extraordinaria Foissner, 2012 and S. elongata Lu et al., 2018. However, in two other Schmidingerothrix species, viz., S. salina (Shao et al., 2017) Lu et al., 2018 and S. salinarum Foissner et al., 2018, the undulating membrane anlage generates the left frontal cirrus I (Foissner et al. 2014, Shao et al. 2014, Lu et al. 2018), as typical of other hypotrichs (Berger 1999, 2006, 2008, 2011). Schmidingerothrix elongata, S. salina and $S$. salinarum form a statistically fully supported cluster ( $\mathrm{Lu}$ et al. 2018) that does not group with the psilotrichids (Luo et al. 2019) in 18S rRNA gene phylogenies. The most parsimonious solution is thus to assume that the first frontal cirrus was secondarily lost in $S$. extraordinaria and $S$. elongata due to oligomerization, as already suggested by Foissner (2012). Thus, the inactivity of the undulating membrane anlage in the production of cirri seems to be a plesiomorphy in psilotrichids but a homoplasy in some schmidingerothrichids. This is corroborated in that (1) euplotids do not have frontal cirri (Lynn 2008) and are a sister to hypotrichs and oligotrichs (Gentekaki et al. 2014, 2017; Lynn and Kolisko 2017), (2) psilotrichids also lack frontal cirri and are placed in a polytomy of the subclass Hypotrichia (Luo et al. 2019), and (3) schmidingerothrichids with and without first frontal cirrus group together in molecular phylogenies ( $\mathrm{Lu}$ et al. 2018). However, we also cannot exclude the possibility that psilotrichids also lost frontal cirri convergently, as indicated by the considerable ontogenetic differences in comparison with euplotids (see below).

Apart from psilotrichids, migrating cirri occur also in the oxytrichine hypotrichs where migrating cirri originate from cirral streak VI and move anteriorly rightwards to form the frontoterminal cirri (Berger 2006). On the other hand, they originate either from streak III or IV and move posteriorly leftwards to form the postoral cirri in psilotrichids (Foissner 1983, Heber et al. 2014, present study). Although the genetic regulatory program behind the migration machinery might be the same, the frontoterminal cirri of oxytrichids and the postoral cirri of psilotrichids are not homologous as they originate from different cirral anlagen and migrate in opposite direction. An oxytrichid relationship of psilotrichids seems unlikely also because oxytrichids ancestrally very likely had dorsomarginal kineties, fragmentation of the third dorsal kinety, and six cirral 
anlagen (Berger 1999, 2011). Psilotrichids do not have dorsomarginal kineties, lack fragmentation of the third dorsal kinety, and show up to five cirral anlagen. The combination of these three features very likely represents a plesiomorphic condition in non-dorsomarginalian hypotrichs because it is a property of euplotids (Foissner 1996, Jiang et al. 2010 and references therein), schmidingerothrichids (Foissner 2012, Foissner et al. 2014, Shao et al. 2014, Lu et al. 2018) as well as of some gonostomatid, kahliellid and deviatid genera (Berger 2011, Foissner 2016).

There are also some conspicuous ontogenetic differences among psilotrichid genera, corroborating their distinction and validity (Heber et al. 2014). The postoral cirral row is ontogenetically inactive in Psilotrichides Heber et al., 2014 while it produces ventral cirral row R3 in Urospinula Corliss, 1960 and the anarchic field in Hemiholosticha Gelei, 1954. The parental undulating membranes are reorganized in Psilotrichides and Hemiholosticha while appearing unchanged in Urospinula. The oral primordium generates one cirral streak in Psilotrichides while two in Urospinula and possibly also in Hemiholosticha. These three genera differ by the origin of the postoral cirral row as well. Specifically, this row develops from the migrating posterior portion of cirral streak III in Psilotrichides, in Hemiholosticha cirral streak III generates only two cirri and both migrate posteriorly leftwards to become the postoral row while the migrating posterior portion of cirral streak IV becomes the postoral row in Urospinula. Finally, Hemiholosticha is outstanding among the psilotrichids in that the longitudinal cirral row R3 originates from two anlagen: the anterior portion comes from cirral streak IV, the posterior one from streak V. Surprisingly, the longitudinal cirral row R3 very likely also forms from anlagen IV and V in some kahliellids (Vd'ačný et al. 2010). On the other hand, the median cirral row develops from anlagen V and VI in most amphisiellids (Berger 2008), indicating that they are not homologous. Molecular phylogenies (Heber et al. 2014, Luo et al. 2019) also indicate that this composite cirral row evolved convergently in Hemiholosticha, Kahliella Corliss, 1960 and amphisiellids. This is indirectly corroborated by Psilotrichides and Urospinula which lack a composite cirral row (Heber et al. 2014).

\section{Homology of anlagen}

For the sake of easy comparison with other psilotrichids, we numbered cirral anlagen according to Heber et al. (2014). In most hypotrichs, anlage I forms the first frontal cirrus and undulating membranes (Berger 1999,
2006, 2008, 2011). However, frontal cirri are not present in psilotrichids (see above), questioning homology of their UM anlage with anlage I of other hypotrichs. If psilotrichids never had frontal cirri, then the homology of their UM anlage with anlage I of other hypotrichs might be problematic. However, if psilotrichids only lost frontal cirri, then it can be anticipated that their UM anlage corresponds to anlage I of other hypotrichs. Consequently, the cirral row R1 would be formed from anlage II, the cirral row R2 from anlage III, the postoral cirral row from anlage IV, and the composite cirral row $\mathrm{R} 3$ from anlagen $\mathrm{V}$ and $\mathrm{VI}$ in $H$. panatanalensis. This is consistent with any hypotrich with at least one postoral cirrus which originates from anlage IV and migrates to the postoral position. Also, the composite row is commonly formed from anlagen V and VI in hypotrichs. Therefore, it is very likely that the undulating membranes anlage of psilotrichids corresponds to anlage I of other hypotrichs and formation of frontal cirri was convergently lost in psilotrichids.

\section{Phylogeny of psilotrichids}

Interphase morphology could not clarify the phylogeny of the psilotrichids (for a review, see Heber et al. 2014) because of the unique combination of the following features: body almost circular to broadly elliptic and rigid, adoral zone prominent, ciliature sparse and undifferentiated, i.e., without distinct frontal, frontoterminal, buccal, pretransverse and transverse cirri. These features might be considered either as ancient plesiomorphies or as result of a secondary reduction. Indeed, a drastic reduction causing an "oligotrich" appearance was evidenced for the oxytrichine hypotrich Halteria Dujardin, 1841 not only by $18 \mathrm{~S}$ rRNA gene phylogenies (Foissner et al. 2004) but also by the extensive phylogenomic analysis based on a set of 124 genes (Lynn and Kolisko 2017). Nevertheless, molecular and ontogenetic data indicate that this might not be the case in psilotrichids because they are placed in a polytomy of the hypotrichs (Heber et al. 2014, Luo et al. 2019) and because they share three possibly ancient ontogenetic plesiomorphies with euplotids: (1) the oral primordium develops in a deep pouch, (2) the undulating membrane anlage does not generate cirri, and (3) the number of cirral streaks is five or less (Foissner 1996, Jiang et al. 2010 and references therein, Heber et al. 2014, present study). Interestingly, euplotids and psilotrichids show a circular to broadly elliptic and rigid body, a prominent adoral zone as well as a sparse and weakly differentiated ciliature. In phylogenomic 
analyses, euplotids are depicted as a sister group of the oligotrich-hypotrich cluster (Gentekaki et al. 2014, 2017; Lynn and Kolisko 2017), which is also strongly corroborated by morphological and ultrastructural data (Foissner et al. 2007). In this light, the morphology and ontogenesis of psilotrichids might be interpreted as full of plesiomorphies. Plesiomorphies are, however, phylogenetically weak and prevent to infer phylogenetic relationships (for a review, see Vd'ačný 2017).

It is also important to mention that psilotrichids cluster within the hypotrich branch of the class Spirotrichea (Luo et al. 2019) and their features might be hence considered as highly convergent with those of euplotids. Indeed, the ontogeny of psilotrichids differs considerably from that of euplotids in that (1) cirri are not formed from long primary streaks, (2) the two rightmost anlagen are formed neokinetally, (3) cirri maturate in an anteriad direction, and (4) transverse cirri are not formed. Development of the oral primordium within a pouch thus might have evolved independently within the Hypotrichia, as a consequence of the reduced size of the posterior body region. Likewise, frontal cirri might have been also lost convergently in psilotrichids. If these assumptions are correct, then the more or less discoid shape, rigid body, dorsal ribs, and stomatogenesis in a pouch would be convergences with euplotids and the morphology as well as ontogenesis of psilotrichids could be interpreted as full of homoplasies.

Acknowledgements. We are grateful to Dr. Barbara Harl, Mag. Michael Gruber, and Robert Schörghofer for technical assistance. We also thank the three anonymous reviewers for valuable insights that helped improve the quality of the manuscript. Financial support was provided by the Austrian Science Fund (FWF Project P26325 B16) and the Wilhelm and Ilse Foissner Stiftung. This work was supported also by the Slovak Research and Development Agency under the contract No. APVV-15-0147 and by the Grant Agency of the Ministry of Education, Science, Research and Sport of the Slovak Republic and Slovak Academy of Sciences under the Grant VEGA $1 / 0041 / 17$.

\section{REFERENCES}

Arthur W. (2011) Evolution: A Developmental Approach. WileyBlackwell, Oxford

Berger H. (1999) Monograph of the Oxytrichidae (Ciliophora, Hypotrichia). Monogr. Biol. 78: 1-1080

Berger H. (2006) Monograph of the Urostyloidea (Ciliophora, Hypotricha). Monogr. Biol. 85: 1-1304

Berger H. (2008) Monograph of the Amphisiellidae and Trachelostylidae (Ciliophora, Hypotricha). Monogr. Biol. 88: 1-737

Berger H. (2011) Monograph of the Gonostomatidae and Kahliellidae (Ciliophora, Hypotricha). Monogr. Biol. 90: 1-741

Bütschli O. (1889) Protozoa. Abt. III. Infusoria und System der Radiolaria. In: Klassen und Ordnung des Thier-Reichs, Vol. I., (Ed. H. G. Bronn). C. F. Winter, Leipzig, 1098-2035
Carroll S. B., Grenier J. K., Weatherbee S. D. (2004) From DNA to Diversity: Molecular Genetics and the Evolution of Animal Design. $2^{\text {nd }}$ ed. Blackwell Publishing, Oxford

Corliss J. O. (1960) The problem of homonyms among generic names of ciliated protozoa, with proposal of several new names. J. Protozool. 7: 269-278

Dingfelder J. H. (1962) Die Ciliaten vorübergehender Gewässer. Arch. Protistenk. 105: 509-658

Dujardin F. (1841) Histoire naturelle des zoophytes. Infusoires. Libraire Encyclopédique de Roret, Paris

Ehrenberg C. G. (1838) Die Infusionsthierchen als vollkommene Organismen. Ein Blick in das tiefere organische Leben der Natur. Verlag von Leopold Voss, Leipzig

Eigner P. (1997) Evolution of morphogenetic processes in the Orthoamphisiellidae n. fam., Oxytrichidae, and Parakahliellidae n. fam., and their depiction using a computer method (Ciliophora, Hypotrichida). J. Eukaryot. Microbiol. 44: 553-573

Esteban G. F., Olmo J. L., Finlay B. J. (2001) Redescription of Psilotricha acuminata Stein, 1859 and revisions of the genera Psilotricha and Urospinula (Ciliophora, Hypotrichida). J. Eukaryot. Microbiol. 48: 280-292

Esteban G. F., Fenchel T., Finlay B. J. (2010) Mixotrophy in ciliates. Protist 161: 621-641

Foissner W. (1983) Morphologie und Morphogenese von Psilotricha succisa (O. F. Müller, 1786) nov. comb. (Ciliophora, Hypotrichida). Protistologica 19: 479-493

Foissner W. (1991) Basic light and scanning electron microscopic methods for taxonomic studies of ciliated protozoa. Eur. J. Protistol. 27: 313-330

Foissner W. (1996) Ontogenesis in ciliated protozoa, with emphasis on stomatogenesis. In: Ciliates: Cells as Organisms, (Eds. K. Hausmann, B. C. Bradbury). Fischer Verlag, Stuttgart, Jena, New York, 95-177

Foissner W. (2012) Schmidingerothrix extraordinaria nov. gen., nov. spec., a secondarily oligomerized hypotrich (Ciliophora, Hypotricha, Schmidingerotrichidae nov. fam.) from hypersaline soils of Africa. Eur. J. Protistol. 48: 237-251

Foissner W. (2014) An update of 'basic light and scanning electron microscopic methods for taxonomic studies of ciliated protozoa'. Int. J. Syst. Evol. Microbiol. 64: 271-292

Foissner W. (2016) Terrestrial and semiterrestrial ciliates (Protozoa, Ciliophora) from Venezuela and Galápagos. Denisia 35: 1-912

Foissner W., Stoeck T. (2008) Morphology, ontogenesis and molecular phylogeny of Neokeronopsis (Afrokeronopsis) aurea nov. subgen., nov. spec. (Ciliophora: Hypotricha), a new African flagship ciliate confirms the CEUU hypothesis. Acta Protozool. 47: $1-33$

Foissner W., Agatha S., Berger H. (2002) Soil ciliates (Protozoa, Ciliophora) from Namibia (Southwest Africa), with emphasis on two contrasting environments, the Etosha region and the Namib Desert. Denisia 5: 1-1459

Foissner W., Filker S., Stoeck T. (2014) Schmidingerothrix salinarum nov. spec. is the molecular sister of the large oxytrichid clade (Ciliophora, Hypotricha). J. Eukaryot. Microbiol. 61: 61-74

Foissner W., Filker S., Stoeck T. (2018) Corrigendum to "Schmidingerothrix salinarum nov. spec. is the molecular sister of the large oxytrichid clade (Ciliophora, Hypotricha) by Foissner et al. 2014”. J. Eukaryot. Microbiol. 65: 290

Foissner W., Moon-van der Staay S. Y., van der Staay G. W. M., Hackstein J. H. P., Krautgartner W.-D., Berger H. (2004) Reconciling classical and molecular phylogenies in the stichotrichines (Ciliophora, Spirotrichea), including new sequences from some rare species. Eur. J. Protistol. 40: 265-281 
Foissner W., Müller H., Agatha S. (2007) A comparative fine structural and phylogenetic analysis of resting cysts in oligotrich and hypotrich Spirotrichea (Ciliophora). Eur. J. Protistol. 43: 295-314

Gelei J. (1954) Über die Lebensgemeinschaft einiger temporärer Tümpel auf einer Bergwiese im Börzsönygebirge (Oberungarn) III. Ciliaten. Acta Biol. Hung. 5: 259-343

Gentekaki E., Kolisko M., Boscaro V., Bright K. J., Dini F., Di Giuseppe G., Gong Y., Miceli C., Modeo L., Molestina R. E., Petroni G., Pucciarelli S., Roger A. J., Strom S. L., Lynn D. H. (2014) Large-scale phylogenomic analysis reveals the phylogenetic position of the problematic taxon Protocruzia and unravels the deep phylogenetic affinities of the ciliate lineages. Mol. Phylogenet. Evol. 78: 36-42

Gentekaki E., Kolisko M., Gong Y., Lynn D. (2017) Phylogenomics solves a long-standing evolutionary puzzle in the ciliate world: The subclass Peritrichia is monophyletic. Mol. Phylogenet. Evol. 106: 1-5

Heber D., Stoeck T., Foissner W. (2014) Morphology and ontogenesis of Psilotrichides hawaiiensis nov. gen., nov. spec. and molecular phylogeny of the Psilotrichidae (Ciliophora, Hypotrichia). J. Eukaryot. Microbiol. 61: 260-277

Heber D., Stoeck T., Foissner W. (2018) Corrigendum to "Morphology and ontogenesis of Psilotrichides hawaiiensis nov. gen., nov. spec. and molecular phylogeny of the Psilotrichidae (Ciliophora, Hypotrichia) by Heber et al. 2014". J. Eukaryot. Microbiol. 65: 291-292

Hu X., Warren A., Song W. (2009) Hypotrichs. In: Free-living Ciliates in the Bohai and Yellow Seas, China (Eds. W. Song, A. Warren, X. Hu). Science Press, Beijing, 353-413

International Commission on Zoological Nomenclature [ICZN] (1999) International Code of Zoological Nomenclature. $4^{\text {th }}$ ed. Tipografia La Garangola, Padova

International Commission on Zoological Nomenclature [ICZN] (2012) Amendment of Articles 8, 9, 10, 21 and 78 of the International Code of Zoological Nomenclature to expand and refine methods of publication. Bull. Zool. Nomencl. 69: 161-169

Jiang J., Shao C., Xu H., Al-Rasheid K. A. S. (2010) Morphogenetic observations on the marine ciliate Euplotes vannus during cell division (Protozoa: Ciliophora). J. Mar. Biol. Assoc. U. K. 90: 683-689

Jung J.-H., Park K.-M., Min G.-S. (2014) Morphology and molecular phylogeny of Pseudocyrtohymena koreana n. g., n. sp. and Antarctic Neokeronopsis asiatica Foissner et al., 2010 (Ciliophora, Sporadotrichida), with a brief discussion of the Cyrtohymena undulating membranes pattern. J. Eukaryot. Microbiol. 62: 280-297

Kahl A. (1932) Urtiere oder Protozoa I: Wimpertiere oder Ciliata (Infusoria) 3. Spirotricha. Tierwelt Dtl. 25: 399-650

Kim J. H., Vd’ačný P., Shazib S. U. A., Shin M. K. (2014) Morphology and molecular phylogeny of Apoterritricha lutea n. g., n. sp. (Ciliophora, Spirotrichea, Hypotrichia): a putative missing link connecting Cyrtohymena and Afrokeronopsis. J. Eukaryot. Microbiol. 61: 520-536

Kreutz M. (2008) Psilotricha viridis - Ein Ciliat mit außergewöhnlichen Zoochlorellen. Mikrokosmos 97: 328-333
Liu W., Jiang J., Xu Y., Pan X., Qu Z., Luo X., El-Serehy H. A., Warren A., Ma H., Pan H. (2017) Diversity of free-living marine ciliates (Alveolata, Ciliophora): Faunal studies in coastal waters of China during the years 2011-2016. Eur. J. Protistol. 61: $424-438$

Lu X., Huang J. A., Shao C., Berger H. (2018) Morphology, cell-division, and phylogeny of Schmidingerothrix elongata spec. nov. (Ciliophora, Hypotricha), and brief guide to hypotrichs with Gonostomum-like oral apparatus. Eur. J. Protistol. 62: 24-42

Luo X., Huang J. A., Li L., Song W., Bourland W. A. (2019) Phylogeny of the ciliate family Psilotrichidae (Protista, Ciliophora), a curious and poorly-known taxon, with notes on two algaebearing psilotrichids from Guam, USA. BMC Evol. Biol. 19: 125

Lynn D. H. (2008) The Ciliated Protozoa. Characterization, Classification and Guide to the Literature. $3^{\text {rd }}$ ed. Springer, Dordrecht

Lynn D. H., Kolisko M. (2017) Molecules illuminate morphology: phylogenomics confirms convergent evolution among 'oligotrichous' ciliates. Int. J. Syst. Evol. Microbiol. 67: 3676-3682

Müller O. F. (1786) Animalcula Infusoria Fluviatilia et Marina, quae Detexit, Systematice Descripsit et ad Vivum Delineari Curavit. Mölleri, Hauniae

Penard E. (1922) Études sur les Infusoires d'Eau Douce. Georg et Cie, Genève

Shao C., Li L., Zhang Q., Song W., Berger H. (2014) Molecular phylogeny and ontogeny of a new ciliate genus, Paracladotricha salina n. g., n. sp. (Ciliophora, Hypotrichia). J. Eukaryot. Microbiol. 61: 371-380

Shao C., Li L., Zhang Q., Song W., Berger H. (2017) Corrigendum to "Molecular phylogeny and ontogeny of a new ciliate genus, Paracladotricha salina n. g., n. sp. (Ciliophora, Hypotrichia) by Shao et al. 2014". J. Eukaryot. Microbiol. 64: 901-902

Stein F. (1859a) Der Organismus der Infusionsthiere nach eigenen Forschungen in systematischer Reihenfolge bearbeitet. I. Abtheilung. Allgemeiner Theil und Naturgeschichte der hypotrichen Infusionsthiere. W. Engelmann, Leipzig

Stein F. (1859b) Characteristik neuer Infusorien-Gattungen. Lotos 9: $57-60$

Stiller J. (1974) Ergänzungen der von Fauré-Fremiet vorgenommenen Neuordnung der hypotrichen Ciliaten. Annls Hist.-Nat. Mus. Natn. Hung. 66: 129-133

Vd'ačný P. (2017) Integrative taxonomy of ciliates: assessment of molecular phylogenetic content and morphological homology testing. Eur. J. Protistol. 61: 388-398

Vd'ačný P., Foissner W. (2012) Monograph of the dileptids (Protista, Ciliophora, Rhynchostomatia). Denisia 31: 1-529

Vd’ačný P., Tirjaková E., Tóthová T., Pristaš P., Javorský P. (2010) Morphological and phylogenetical studies on a new soil hypotrich ciliate: Kahliella matisi spec. nov. (Hypotrichia, Kahliellidae). Eur. J. Protistol. 46: 319-333

Received on $4^{\text {th }}$ July, 2019; revised on $30^{\text {th }}$ September, 2019; accepted on $23^{\text {rd }}$ October, 2019 